\title{
Agronomic Advancement in Tillage, Crop Rotation, Soil Health, and Genetic Gain in Durum Wheat Cultivation: A 17-Year Canadian Story
}

\author{
Lin Li ${ }^{1,+}$, Yining Niu ${ }^{1,2,+} \mathbb{D}$, Yuefeng Ruan ${ }^{1}$, Ron M. DePauw ${ }^{3}$, Asheesh K. Singh ${ }^{4}$ \\ and Yantai Gan $1, * \mathbb{1}$ \\ 1 Agriculture and Agri-Food Canada, Swift Current Research and Development Centre, \\ Swift Current, SK S9H 3X2, Canada; Lin.li@agr.gc.ca (L.L.); Yuefeng.ruan@agr.gc.ca (Y.R.) \\ 2 Gansu Provincial Keylab of Aridland Crop Sciences, Gansu Agricultural University, Lanzhou 730070, China; \\ Niuyn@gsau.edu.cn \\ 3 Advancing Wheat Technology, 870 Field Drive, Swift Current, SK S9H 4N5, Canada; rdepauw@secan.com \\ 4 Department of Agronomy, Iowa State University, Ames, IA 50011-1010, USA; singhak@iastate.edu \\ * Correspondence: yantai.gan@Canada.ca \\ + These authors contributed equally to this work.
}

Received: 4 August 2018; Accepted: 11 September 2018; Published: 18 September 2018

\begin{abstract}
The global demands for various grains, including durum wheat (Triticum turgidum L. subsp. durum (Desf.) Husn.), are expected to increase substantially in the coming years, due to the ever-growing human population's needs for food, feed, and fuel. Thus, providing consistent or increased durum grain to the world market is one of the priorities for policy-makers, researchers, and farmers. What are the major achievements in agronomic advancement for durum wheat cultivation in recent decades? How might the current cropping systems be improved to increase crop yield and quality and improve resource use efficiencies while minimizing input costs and decreasing negative impact on the environment? Canada is one of the major durum wheat producers in the world, as Canada contributes about 50\% to global trade of durum grain. Canada's research achievements in durum wheat might serve as a guide for advancing the cultivation of the crop in other regions/countries on the planet. This review summarizes the major Canadian research findings in the aspects of durum wheat agronomics during the period 2001 to 2017 years. It highlights the main advancements in seeding and tillage, crop rotation and diversification, and use of pulse-induced microbiomes to improve soil health and feedback mechanisms. The genetic gain and breeding for resistance against abiotic and biotic stresses are discussed. Finally, we identified the main constraints and suggested some near-term research priorities. The research findings highlighted in this review will be of use for other areas on the planet to increase durum wheat productivity, improve soil fertility and health, and enhance long-term sustainability.
\end{abstract}

Keywords: Triticum durum; cropping systems; microbiome; fertilization; tillage; breeding; environmental footprint

\section{Introduction}

The global demands for major grains, such as durum wheat, are projected to increase substantially in the coming decades [1], driven by the ever-growing human population's need for food and fuel [2,3]. Canada is one of the major grain producers in the world. In particular, Canada provides a significant proportion of durum wheat to international trade. For example, between 2016 and 2017, world durum wheat production totaled about 40 million tons (MT), of which Canada contributed 7.8 MT, accounting for $20 \%$ of the world durum wheat production (Figure 1). Other large durum wheat 
producers are European Union at 9.4 MT, North Africa at 3.5 MT, the Turkey and Syria region at 6.2 MT, Mexico at 2.5 MT, and USA at 2.8 MT. Canada plays a significant role in ensuring a constant supply of durum wheat to the world market by contributing about $50 \%$ to global trade of durum wheat [4]. With the concern of the global food security and Canada's position of producing a sufficient quantity of durum wheat for the world, many questions arose in recent years among policy-makers, research professionals, market personnel, grain producers, food processors and consumers, and the general public: How Canada might be able to provide consistent or increased durum wheat production to alleviate the pressure of global food security? What are the major achievements and constraints in durum wheat production in the major durum wheat-growing area in Canada? How can the current cropping systems be improved to increase crop yields and quality, improve resource use efficiencies, and enhance soil health, while minimizing input costs and decreasing the negative impact on the environment?

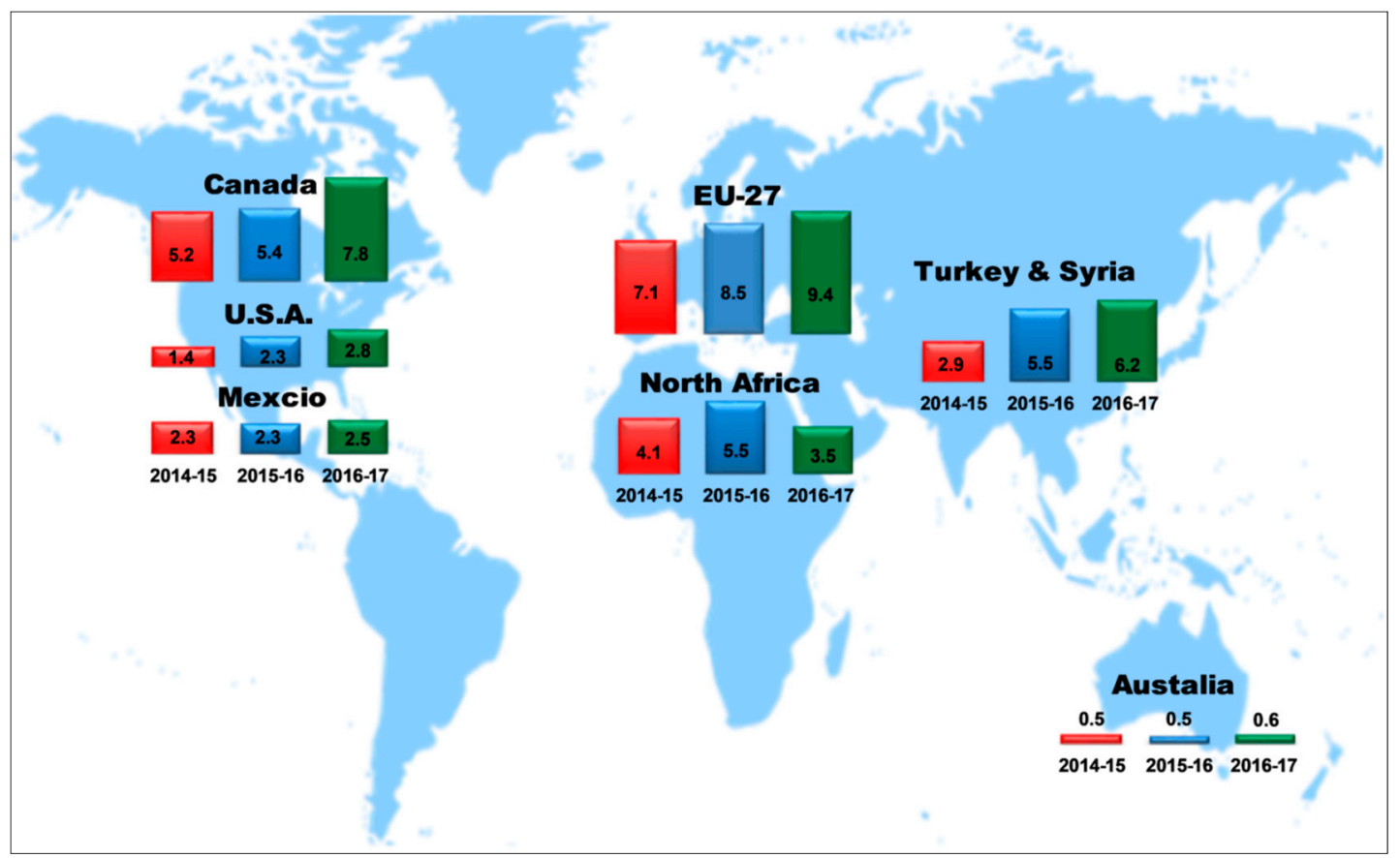

Figure 1. Durum wheat production in different regions from 2015 to 2017, with the world durum wheat production totally 33 million tons (MT) from 2014 to 2015, 39 MT from 2015 to 2016, and 40 MT from 2016 to 2017 [5].

The objective of this work is to provide some answers to these questions by summarizing the major Canadian research and production findings in the area of durum wheat agronomy during the period 2001 to 2017. Our findings are based mainly on (i) literature review on agronomic aspects of Canadian durum wheat research and production; (ii) a comprehensive database of Saskatchewan Crop Insurance Corporation (SCIC), where the majority of the durum wheat producers are documented for their production input, output, and other relevant specifics; and (iii) statistical data from relevant governmental organizations, such as Statistics Canada and International Grains Council. The review highlights agronomic advancement in durum wheat cultivation, identification of constraints, and an outline of genetic changes in grain yield and protein concentration, and breeding for enhancement against abiotic and biotic stresses. Finally, we suggest some near-term research priorities. We suggest that the research findings summarized in this review will be of use for other areas on the planet to increase wheat productivity, improve soil health, and enhance long-term sustainability. 


\section{Production Background}

Canadian durum wheat is mainly grown in the semiarid Brown (Aridic Haploborolls) and Dark Brown (Typic Borolls) soil-climatic zones of the Canadian prairies (Figure 2). Average grain yield of Canadian durum wheat during 2001-2017 was $2.37 \mathrm{t} \mathrm{ha}^{-1}$, ranging from 1.49 to $3.33 \mathrm{t} \mathrm{ha}^{-1}$ annually (Figure 3). During 2001-2017, overall durum wheat grain yield has increased by an average of $70.2 \mathrm{~kg} \mathrm{ha}^{-1}$ per year $\left(r^{2}=0.54^{* *}\right)$. The increased grain yield over the years is attributable to both genetic enhancement and agronomic practices (Sections below). Within the durum wheat production area, the largest producer is the province of Saskatchewan, where 1.8 million hectares durum wheat are grown annually, with the total grain volume accounting for $>84 \%$ of the total Canadian durum wheat production (Figure 4). Saskatchewan is recognized, worldwide, as a consistent and reliable supplier of nutritious, high-quality durum grain [6]. However, the durum wheat cropping systems on the prairie face significant challenges.

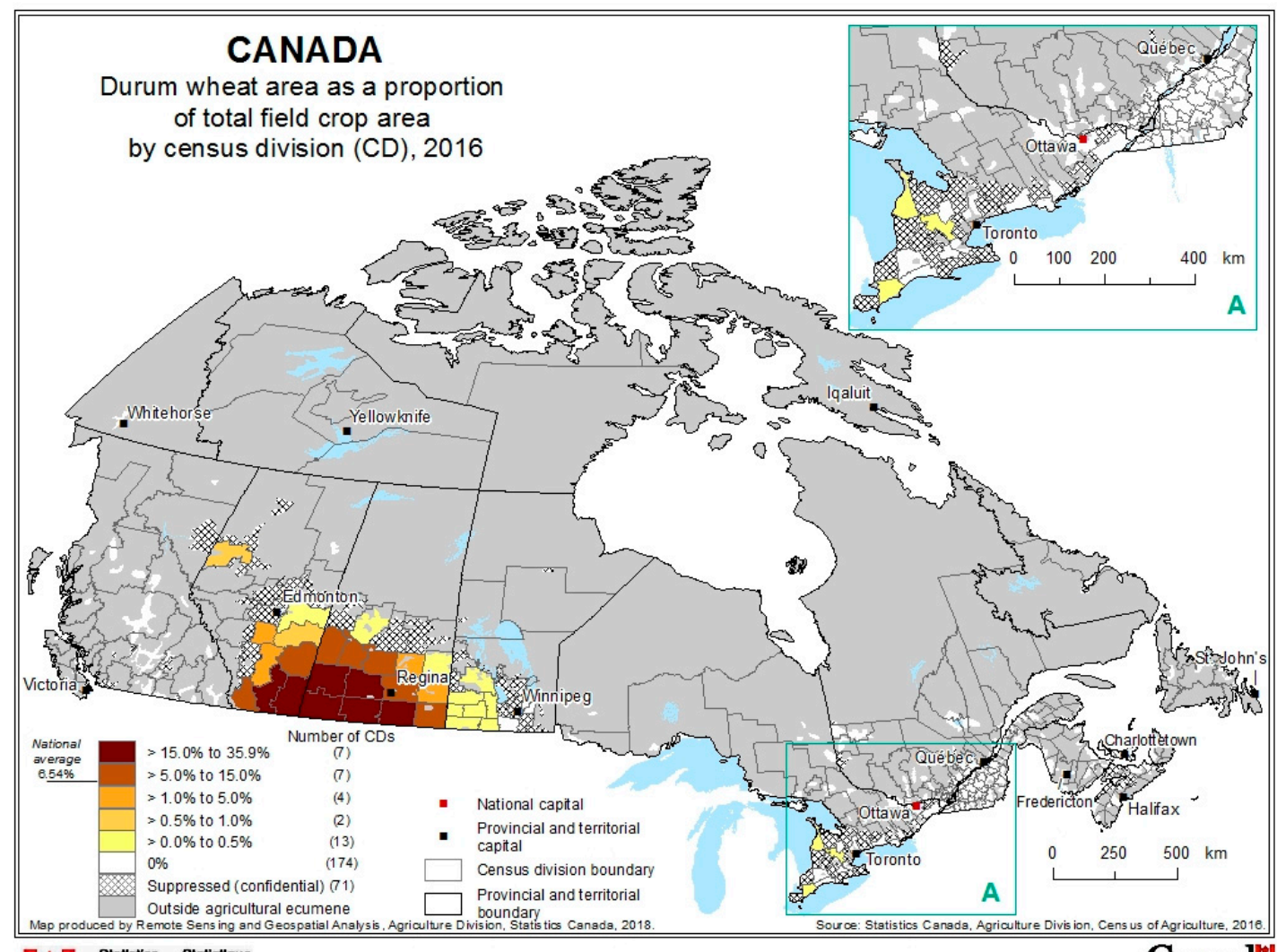

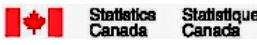

Canadầ

Figure 2. The majority of the Canadian durum wheat-growing areas [6]. 


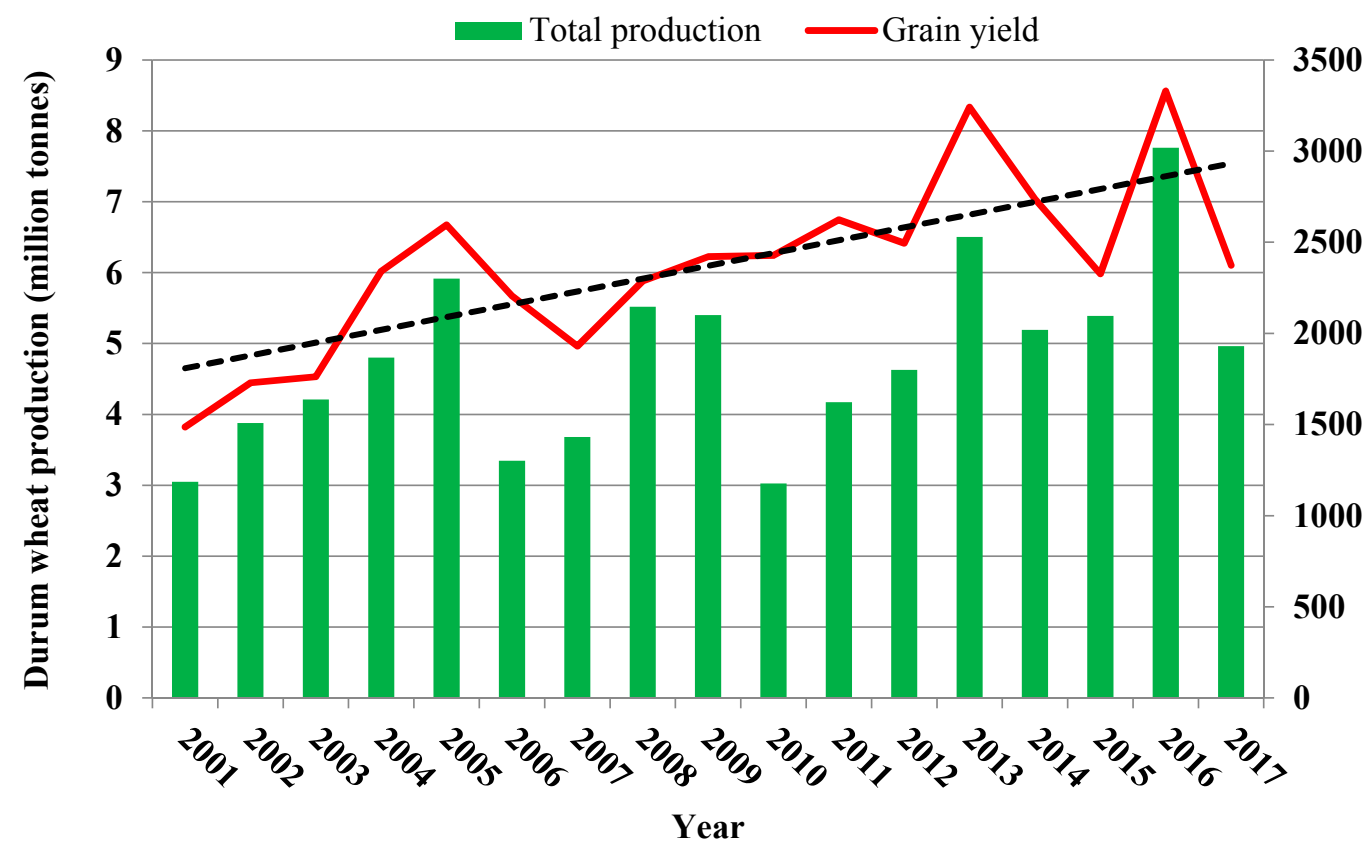

Figure 3. Canadian durum wheat production (in million tons) and average grain yield (in $\mathrm{kg} \mathrm{ha}^{-1}$ ) from 2001 to 2017 [7]. Linear relationship (in dotted line) between grain yield and year was grain yield $=70.2 \times$ year +1739.1 .

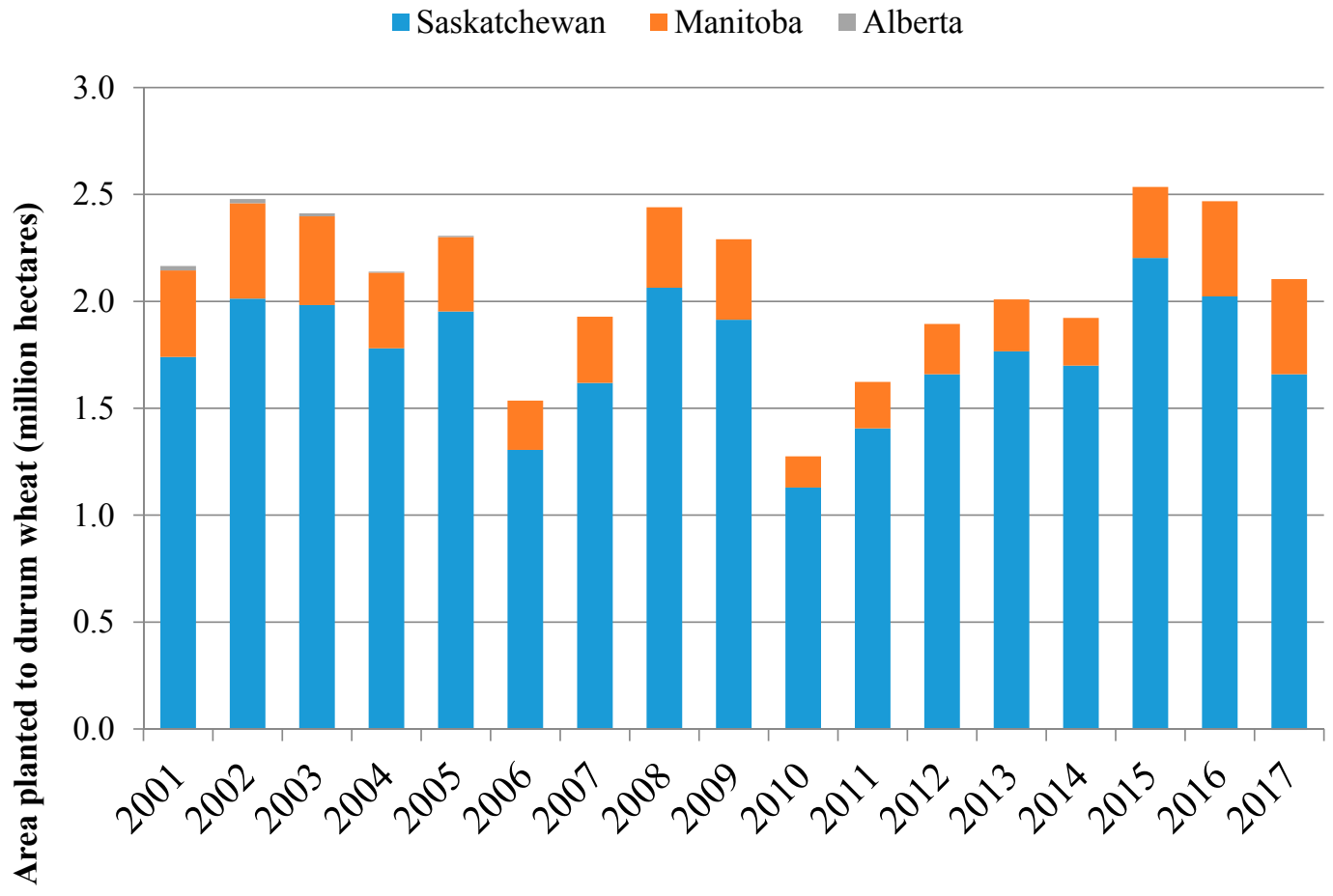

Year

Figure 4. Distribution of durum wheat areas on the Canadian prairies [8].

The first challenge is moisture, a primary factor that limits crop production on the Canadian prairie [9]. The Brown soil zone on the Canadian prairie has a long-term (1930-2016) average annual precipitation $370 \mathrm{~mm}$ and a growing-season (1 May-31 August) precipitation of $224 \mathrm{~mm}$. The annual moisture deficit (i.e., potential evapotranspiration minus precipitation) for the region ranges from 250 to $400 \mathrm{~mm}$ per year, representing one of the driest ecoregions in the world [10]. The Dark Brown soil zone is characterized by annual precipitation in the range of 320 to $380 \mathrm{~mm}$, with a fairly high 
annual potential evapotranspiration in the range of 600 to $700 \mathrm{~mm}$, and less frequent droughts than the Brown soil zone [10]. With the changing climate on the Canadian prairies, extreme precipitation patterns or unpredictable variation (year-to-year, or season-to-season) of weather conditions may occur moving forward [11]; this will definitely place large pressure to durum wheat productivity in the future [12].

The second challenge to durum wheat productivity on the prairie is the low soil fertility [13]. The brown color of the surface soil in the Brown soil zone indicates lower organic matter (1.5 to $2.0 \%$ or $<20 \mathrm{~g} \mathrm{~kg}^{-1}$ in the $0-15 \mathrm{~cm}$ depth) with poor soil quality [14,15]. The dark-brown color of the surface soil in the Dark-Brown soil zone indicates a moderate amount of soil organic matter (2.0 to $3.0 \%$ or about $30 \mathrm{~g} \mathrm{~kg}^{-1}$ in the $0-15 \mathrm{~cm}$ depth) with moderate soil fertility. These challenges may have limited durum wheat productivity on the prairie.

\section{Agronomic Advancement}

The terms "Best Management Practices" (BMP) [16-18] and "Beneficial Management Practices" [19-21] have been widely used to describe agronomic practices that affect crop production and outcomes. The former term describes how BMPs affect plant growth and development, crop yield and quality, and input use efficiencies, while the latter term highlights the beneficial effects of cropping practices on those issues beyond crop production. In this review, we use both BMP terms to describe key cultivation practices, and highlight those that affect durum wheat production on the Canadian prairie most.

\subsection{Decisions on Seeding Date and Seeding Rate}

The growing season on the Canadian prairie is short [22]. In a normal year, the season starts in late April to early May, and ends with the first frost, occurring in early September [23]. Therefore, seeding date is very important for many crops to mature, including the longer-season durum wheat crop. Overall, research on the effects of seeding date on durum wheat productivity is limited, but a number of studies have shown that an earlier seeding usually increases durum wheat crop yield. For example, in a 4-year irrigated field experiment conducted on both Brown and Dark Brown Chernozem soils in southern Alberta, McKenzie, Bremer [24] found that a one-day delay in seeding after 30 April resulted in $1.3 \%$ yield decrease per day. However, the magnitude of the effect of seeding date varies with many factors, such as spring soil moisture and temperature, growing season weather conditions, soil type, and cultivars.

The data from 176,679 Saskatchewan durum wheat producers recorded by Saskatchewan Crop Insurance Corporation (SCIC) revealed that the most of Canadian durum wheat growers planted their durum crops between 6 May and 20 May, ranging from 15 April to 17 June, during the period 2001 to 2015 (Figure 5). Seeding date affected durum wheat grain yield significantly. Seeding durum wheat in April showed substantial variation in durum grain yield. This is likely due to variable soil temperature in the major durum wheat-growing area on the Canadian prairie. Low soil temperature may decrease seed germination and seedling emergence, and increase the occurrence of root rotting pathogens [25]. In some years, the soil starts warming up in mid- to late-April, and farmers start seeding the crops, but a subsequent killing frost $\left(-5\right.$ to $\left.-7^{\circ} \mathrm{C}\right)$ may occur [26], causing some vegetative growth damage and, thus, lowering crop yield. Precipitation during the period near the end of June through early July, approximating the time of anthesis, has the highest correlation with grain yield [27]. A delay of seeding to early June also significantly decreased the grain yield and increased the performance variability [24]. This is probably related to a shortened vegetative growth period due to later seeding. Shortening vegetative growth period decreases the transportation of photosynthetes from vegetative tissues to the grain sinks. 


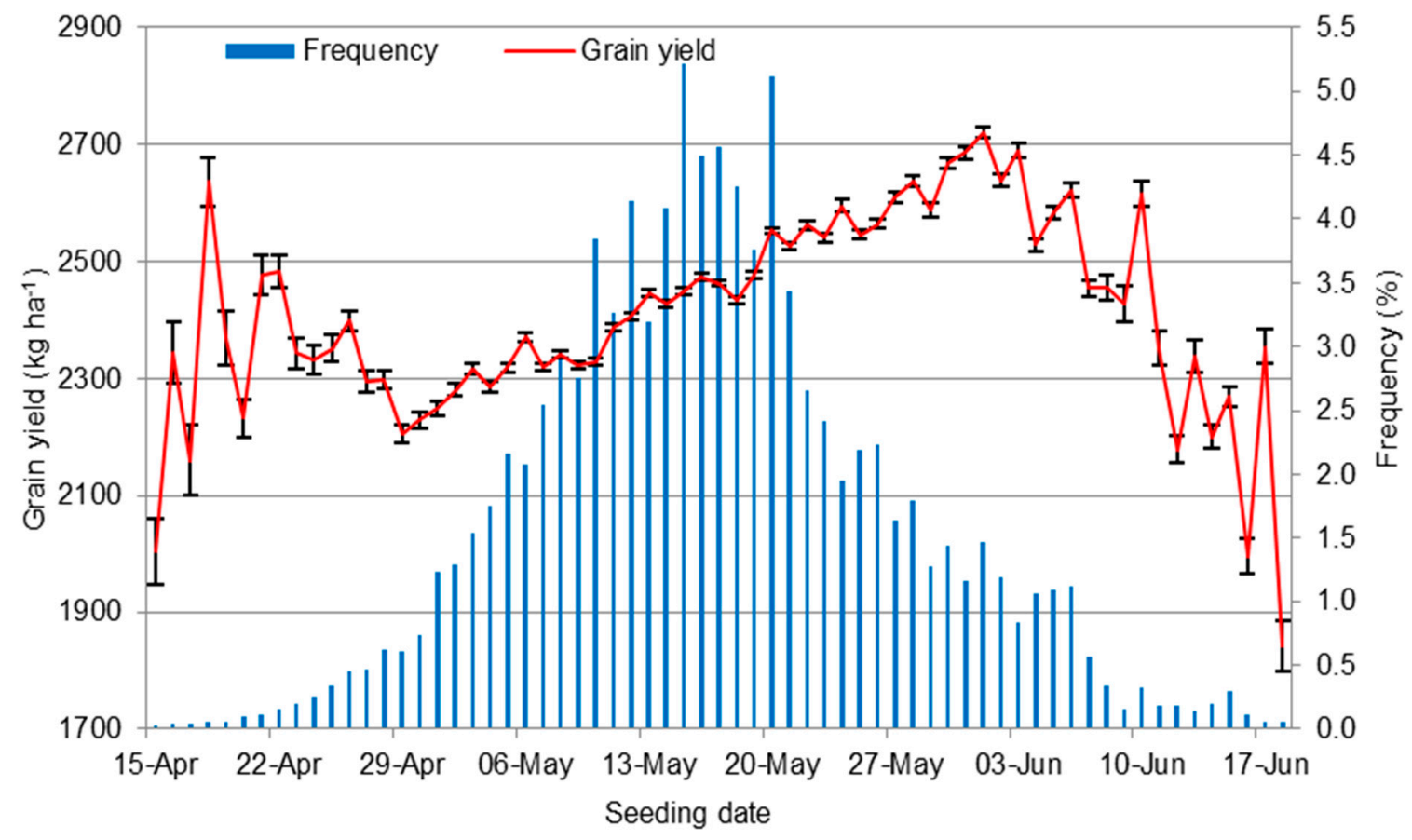

Figure 5. Effect of seeding date on durum wheat grain yield and the distribution frequency (Source: Saskatchewan Crop Insurance Corporation, $n=176,679$ individual durum wheat growers from 2001 to 2015). The line bars at each point of grain yield are standard errors.

A delay of seeding to early June also significantly decreased the grain yield and increased the performance variability. During the month of May, a delayed-seeding increased the durum wheat grain yield. It is unknown why a delay of seeding in May actually increased the grain yield in the growers' fields, which differs from the findings from small plot irrigated experiments in Southern Alberta [24]. Anecdotally, during the month of May, farmers make a conditional planting decision based on soil moisture, temperature, and rainfall. If there is a major rainfall event, about $50 \mathrm{~mm}$, farmers most likely make additional plantings of durum wheat. It is well known that the efforts of matching weather variables (temperature and precipitation) with plant photosynthetic activity plays a key role for grain formation. It can be argued that the growers' results might have been confounded with many other crop management factors. However, the data from more than 176,600 growers may be representative of the real world situation and, statistically, they could be considered as a universal sampling rather than experimental data [28]. In other small plot experiments with dry pea (Pisum sativum L.) and canola (Brassica napus L.), early-seeding has been found to increase grain yield [29-31], due to better use of soil reserved water, improved use of soil N [31,32], and enhanced plant establishment [25].

The inconsistent results on seeding date effect prompted us to suggest two important areas of research to be considered in the future. First, an optimal seeding date for durum wheat should be determined for each district of the durum wheat production areas. Combination of mechanistic and systems-based modelling using weather data, crop growth and development, soil conditions, crop management practices, and incidence and severity of plant pathogens, are to be used to predict an optimized seeding date for durum wheat. Models, such as decision support system for agrotechnology transfer cropping system model (DSSAT-CSM) is one example of such approaches [26]. The study of seeding date with a model approach may have the advantages of finding the corresponding yield responses based on different parameters in the model manipulations. Second, there is a need to develop cultivar-specific cultivation practices, including seeding date. About two dozen new durum wheat cultivars have been released since 2009. Each cultivar may pose a different genetic background in terms of photoperiod sensitivity, and response to moisture availability and heat stress. Information on the relative sensitivity of cultivars to seeding dates is currently lacking 
for Canadian durum wheat cultivars. Understanding the sensitivity of each cultivar to seeding date, in conjunction with other relevant variables (soil, crop, pathogen, and environment), will help growers to make firm decisions on when and which cultivars to seed under a specific condition.

Seeding rate can be manipulated to optimize the ability of the crop to use available resources to achieve maximum yield $[33,34]$. Seeding rate may vary among regions according to climatic conditions, soil type, sowing time, and planting equipment design. Furthermore, seeding rate has to be adjusted to account for seed germination rate, vigor, and emergence mortality. Recent studies support using higher seeding rates, up to 400 seeds $\mathrm{m}^{-2}$ from the traditional 175 to 250 seeds $\mathrm{m}^{-2}$. In a study where durum and spring wheat were planted into wheat stubble the durum cultivar, AC Avonlea [35] displayed significant linear grain yield responses to the highest seeding density of 450 seeds $\mathrm{m}^{-2}$ [36]. Comparing solid stem cultivars to a hollow stem cultivar, the highest grain yields did not differ among seeding rates from 250 to 450 seeds $\mathrm{m}^{-2}$ [37]. Stem pith expression, a strategy to control the wheat stem sawfly (Cephus cinctus Norton), was linear and negative for each internode, and maximum average stem pith expression was achieved at sowing rates below 450 seeds $\mathrm{m}^{-2}$. Similarly, the response of eight new durum varieties to seeding rates varying between 163 to $380 \mathrm{~m}^{-2}$, displayed an optimum seeding rate of 217 to 326 seeds $\mathrm{m}^{-2}$, depending on the location [34]. Among these new cultivars, a cultivar by seeding rate interaction was not reported [34,37].

\subsection{Selection of Land and Tillage}

On the Canadian prairies, durum wheat, similar to hard red spring wheat, was traditionally grown in summerfallow-cereal-cereal or continuous cereal systems [38]. In the summerfallow year, the land is left unplanted for the entire growing season with loss of a crop opportunity. Summerfallowing practices have two major benefits to crop production. First, it conserves rain water, whereby a portion of rainfall during the summerfallowing period is reserved in the soil, which is available for the crops grown the following year [39]. Thus, this is an important strategy to combat drought in arid and semiarid areas. Second, the soils during summerfallowing period release $\mathrm{N}$ via the mineralization of organic matter [40]; this helps reduce the amount of inorganic fertilizers required by crops. Soil net $\mathrm{N}$ mineralization usually increases with higher soil water availability [41]. Therefore, $\mathrm{N}$ mineralization of soil organic matter is usually greater in summerfallow than in stubble land [42]. However, a Saskatchewan study showed that nitrate-N content in the $0-60 \mathrm{~cm}$ soil depth measured in October did not differ between summerfallow and continuous wheat systems [42], suggesting that part of $\mathrm{N}$ mineralized from soil organic matter may have been lost during the summerfallow period. However, the data from durum wheat producers on the Canadian prairie during the period 2001-2015 show that producers growing durum wheat on summerfallowing applied inorganic $\mathrm{N}$ fertilizer averaging $40.5 \mathrm{~kg} \mathrm{~N} \mathrm{ha}^{-1}$, and P fertilizer averaging $22.9 \mathrm{~kg} \mathrm{P} \mathrm{ha}^{-1}$ annually, which was $30 \%$ and $8 \%$ lower, respectively, than durum wheat grown in stubble fields (Figure 6). In the Brown and Dark-Brown soil-climatic zones, summerfallowing practices only stores about $20 \%$ of the total rainfall occurring during the summerfallow period, and $80 \%$ of the rain water is lost through evaporation [43]. Furthermore, crops grown on summerfallow can uptake a substantially higher amount of $\mathrm{N}$ than the amount of $\mathrm{N}$ applied through fertilizers; this may lead to the propensity of mining $\mathrm{N}$ from the soil [32]. Also, summerfallowing practices lead to a fast decomposition of soil organic matter, leading to depletion of soil carbon over the long term [44], and possesses risks of soil erosion and denitrification [45]. 


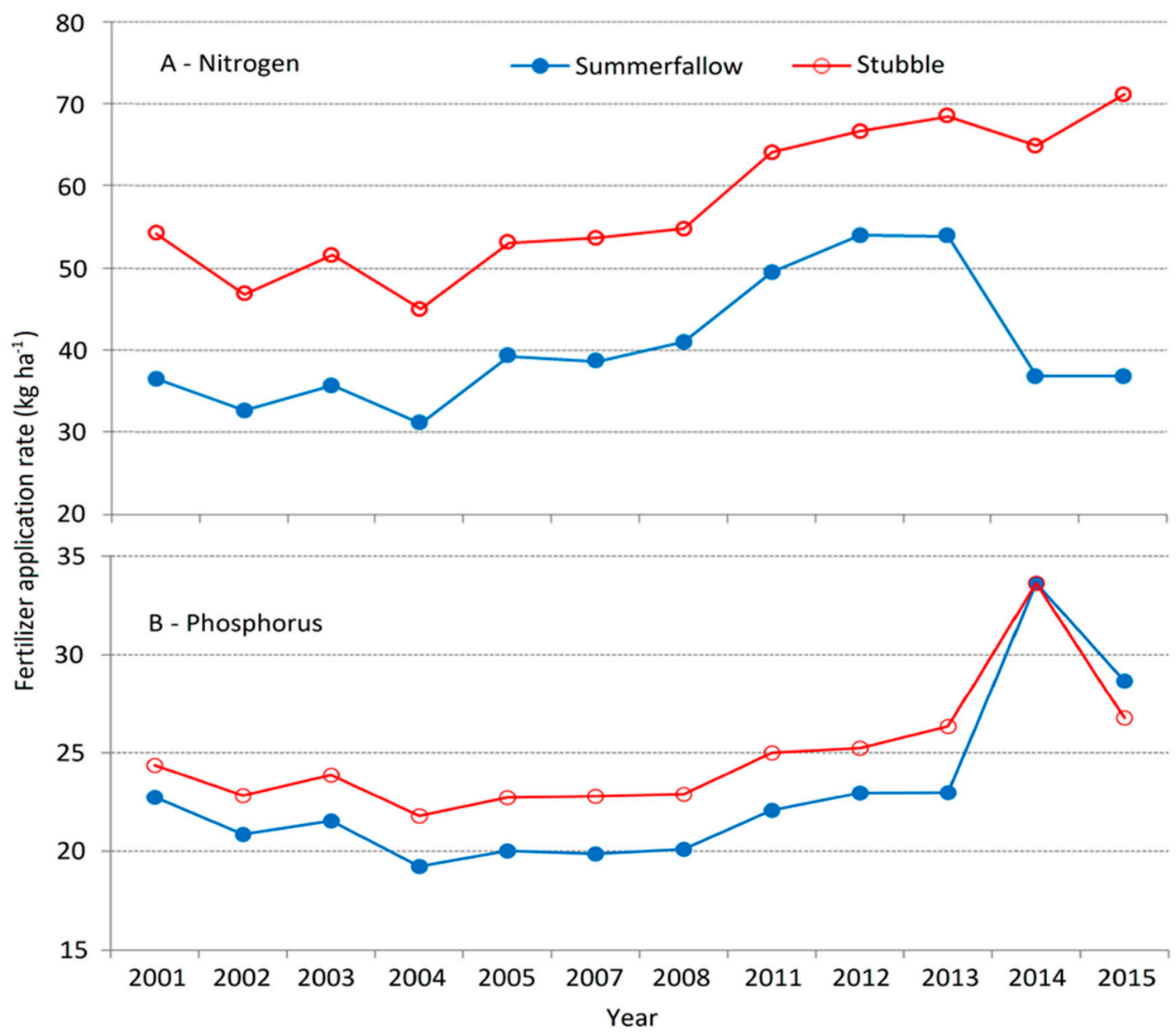

Figure 6. Nitrogen $(\mathrm{N})$ and phosphorus $(\mathrm{P})$ fertilizers used for durum wheat grown on summerfallow versus on stubble fields in Saskatchewan during 2001-2015 (Source: Saskatchewan Crop Insurance Corporation, $n=8657$ individual durum wheat growers (2001-2013) and Saskatchewan Crop Planning Guide in 2014-2015).

Small plot field experiments have demonstrated that the grain yield of durum wheat grown following summerfallow is higher than when grown on stubble lands $[42,46,47]$. Similarly, the data from 361,683 durum wheat growers recorded at the SCIC database showed that during 2001-2015, durum wheat grown on summerfallow had an average grain yield of $2.54 \mathrm{t} \mathrm{ha}{ }^{-1}$, which was $7.5 \%$ greater than those grown on stubble (Figure 7). The annual precipitation and growing season precipitation were higher than the long-term averages in 2002, and from 2010 to 2014 inclusive. The yield difference between summerfallow and stubble can be substantial in drier years, such as 2001, because of the extra moisture reserved in the summerfallow fields. Thus, summerfallowing practices are considered a means of reducing crop failure and net return risk [48]. However, the inclusion of summerfallow in a crop rotation system loses one-year cropping opportunity. Another significant drawback of growing durum wheat on summerfallow is the increased fossil fuel required for the multiple tillage operations for weed control [49] that contributes to greenhouse gas emissions [50] during the summerfallowing period, when no crop is grown. A body of evidence has shown that the summerfallowing practices can have serious environmental consequences [51,52]. High frequency of fallowing depletes soil carbon [53], causes soil erosion [51], and increases the carbon footprint of the grain products [54]. 


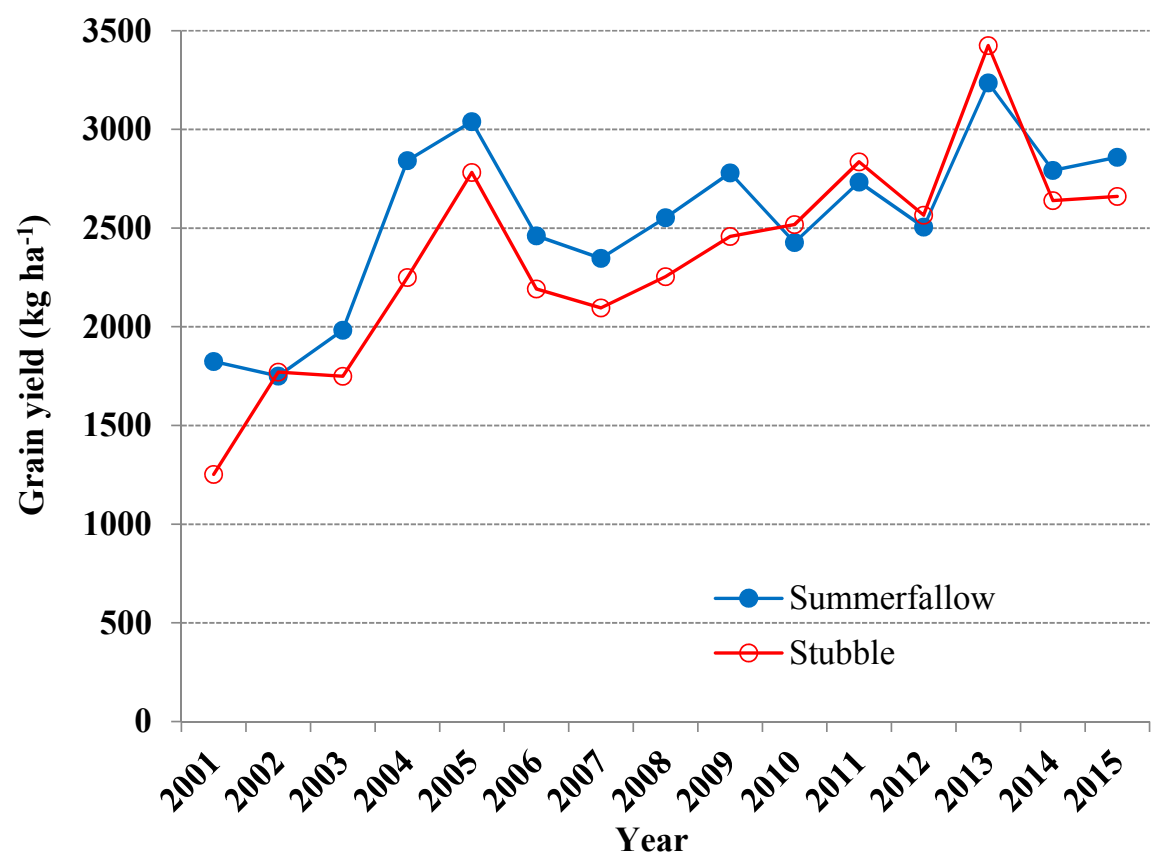

Figure 7. Average grain yield of durum wheat grown on summerfallow versus on stubble fields during 2001-2015 in Saskatchewan (Source: Saskatchewan Crop Insurance Corporation, $n=361,683$ individual durum wheat growers (2001 to 2013) and Saskatchewan Crop Planning Guide in 2014-2015).

The area of summerfallowing practices has declined significantly in recent years. For example, the proportion of durum wheat grown on summerfallow area in Saskatchewan decreased from 39\% of total arable lands in 2001 to $16 \%$ in 2013 (Figure 8). A reduction of summerfallow frequency in the cereal-based cropping system has been found to increase annualized grain yield relative to a system with higher frequency of summerfallow [54]. A strategy is to substitute summerfallow in a rotation with legume green manure crops [55]. Black lentil (Lens culinaris Medik.), chickling vetch (Lathyrus sativus L.), and forage pea (Pisum sativum L.) have been used as green manure legumes on the prairie [13].

Inclusion of green manures in rotation systems increases the system productivity. In a Saskatchewan study, the preceding green manures increased subsequent durum wheat grain yield by $19 \%\left(0.28 \mathrm{t} \mathrm{ha}^{-1}\right)$ compared with preceding dry pea and silage pea and by $54 \%\left(0.67 \mathrm{tha}^{-1}\right)$, compared with preceding spring wheat [13]. The increased durum wheat yield was largely due to benefits from soil moisture conservation and soil $\mathrm{N}$ contributed by the green manure. The study found that soil moisture conserved with green manures sown later in the summer was comparable to that conserved under summerfallow. The use of leguminous green manures has additional benefits in that the legume crop contributes $\mathrm{N}$ to the soil through symbiotic $\mathrm{N}$ fixation. This decreases the use of inorganic $\mathrm{N}$ fertilizer [56] and increases systems productivity [57]. However, a green manure crop foregoes a grain crop. The decision to grow legume green manure crop or a legume crop for the grain will depend on careful planning that involves cost-benefit analysis and short- and long-term outlook for farm profitability, soil health, and environmental sustainability. 


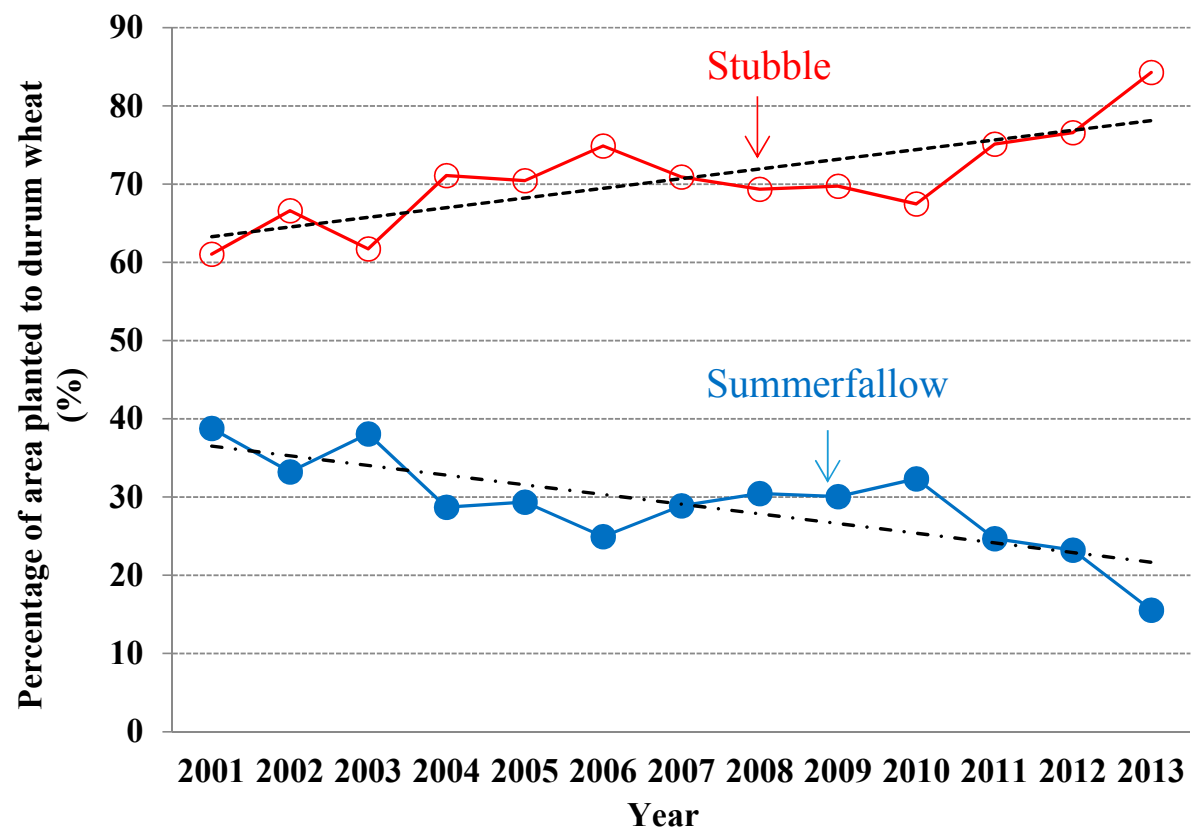

Figure 8. The proportion of Canadian durum crops area grown on summerfallow versus on stubble fields in Saskatchewan from 2001 to 2013 (Source: Saskatchewan Crop Insurance Corporation, $n=361,684$ individual durum wheat growers). The relationship between percent stubble area and year was: $\%$ stubble area $=0.0124 \times$ year +0.6 (the top line); the relationship between percent summerfallow and year was: $\%$ summerfallow area $=-0.0124 \times$ year +0.4 (the bottom line).

\subsection{Diversification of Crop Rotations}

In the past two decades, various pulse crops, such as lentil (Lens culinaris Medik.), chickpea (Cicer arietinum L.), field pea, along with small-seeded oilseed crops, such as canola (Brissica napus L.), mustard (Brassica juncea L., Brassica carinata L., and Sinensis alba) and camelina (Camelina sativa L.), have been included in the cereal-based cropping systems using no-till management practices [58,59]. Since then, Canadian durum wheat has been produced in the pulse- and oilseed-based, diversified cropping systems. It is considered that the diversified cropping systems, an alternative to the traditional summerfallow-cereal-cereal system, are one of the major innovations in the history of Canadian field crop production.

Many studies have reported that inclusion of pulse or oilseed crops as alternatives to cereal monoculture systems increases durum wheat productivity. In a three-year cropping system study in southern Saskatchewan with durum wheat as the subsequent crop, following pulse crops (lentil, chickpea and dry pea) and oilseed crop (canola or mustard) and spring wheat as the preceding crops in the precious two years, researchers found that the cropping sequences had a significant effect on durum wheat productivity $[9,60,61]$. Inclusion of the pulse/or oilseed crop in one of the previous two years increased the grain yield of subsequent durum grain by $15 \%$ (equivalent to $0.33 \mathrm{tha}^{-1}$ ) compared with continuous wheat systems. In a similar study of cropping sequences on the Orthic Brown Chernozem soil, the wheat-pulse-durum system increased durum wheat yield in Year 3 of the rotation by $60 \%$ or $0.77 \mathrm{tha}^{-1}$ compared with durum wheat in a cereal monoculture system averaged over five rotation cycles [57].

Lentil and dry pea are the most common pulse crops preceding durum wheat on the Canadian prairie. A pulse-durum wheat rotation system has been shown to have significant advantages in soil water use and $\mathrm{N}$ supply, compared with cereal-based monoculture systems. The magnitude of the rotational effect on the following durum wheat varies with the different species and cultivars of the pulse crops grown the previous year $[43,62,63]$. The mechanisms responsible for the increased productivity of durum wheat following annual pulses are unclear. However, a body of evidence has shown that it is mainly related to the following three aspects. 


\subsubsection{Soil Water}

Water is key to crop production in the semiarid Canadian prairie [64,65]. The soil available water at planting is critical for seed germination, stand establishment, and early plant growth. The inclusion of annual pulses in rotation with cereals increases the available water in the soil profile, which benefits the cereal crops the subsequent year. Annual pulse plants have a shallower rooting depth with 77 to $85 \%$ of the roots being located in the $0-40 \mathrm{~cm}$ soil depth with little roots $(<6 \%)$ beyond the $60 \mathrm{~cm}$ depth, while wheat plants root to at least $100 \mathrm{~cm}$ depth in lysimeters [66,67]. These pulses use 15 to $35 \%$ less water during a crop season than cereal or oilseed crops [68]. Also, pulse crops extract water mostly from the upper $60 \mathrm{~cm}$ soil depth and, thus, crop rotations with pulse crops had the highest soil water contents in the $60-90 \mathrm{~cm}$ layer than any other rotation systems [69]. The unused water below $60 \mathrm{~cm}$ may become "plant-available water" that benefits the following durum wheat. Also, the period, from crop harvest to the following spring seeding, is about seven to nine months in western Canada. During this time, the topsoil $(0-40 \mathrm{~cm}$ layers) profile can be recharged through rain water in the late-fall and early spring. Also, snow captured by crop residue contributes additional "snow melt water" thereby increasing soil water storage [70,71]. A large proportion of the recharged soil water through snow melt may become "plant-available water" for the subsequent crop. However, precipitation during a growth season plays a more dominant role in determining durum wheat crop yield than available water in the soil at the seeding time in semiarid region of Saskatchewan [65].

Soils may have a proportion of water remaining in the $0-1.2 \mathrm{~m}$ profile at crop harvest in years with above average precipitation. The amount of residual soil water greater than permanent wilting point is considered "available water", that is available to the crops the following year. Permanent wilting point is a function of soil texture which varies across space and depth. In the durum wheat-growing areas of western Canada, in the years with above-average precipitation, the amount of residual soil moisture can be greater than $134 \mathrm{~mm}$, the "permanent wilting point" [72]. Some available water remains in the soil profile after crop harvest, suggesting that the crops were unable to utilize all the water that was available during the growing period.

Another important factor relevant to soil water availability is frost-free days. Average frost-free days are $114.3 \pm 1.6 \mathrm{~d}$ over the 126 years of recorded data in the major durum wheat-growing area of southwestern Saskatchewan [73]. The short growing period may not give some crops sufficient time to utilize all the water resources available to maximize yield potential. For durum wheat, the killing frost temperature is about $-2.2{ }^{\circ} \mathrm{C}$. Therefore, in a normal year, the growing season starts with last spring killing frost in mid- to late-April, and ends with the first killing fall frost occurring in midto late-September. The average killing frost-free period ranges from 135 to 160 days in the Brown and Dark Brown soil zones of Western Canada [74]. Normally, the durum crop must be matured and harvested before the weather conditions become inclement with declining temperatures, short days, and risk of snow.

\subsubsection{Soil Nutrients}

The inclusion of pulses in crop rotation enhances soil mineral $\mathrm{N}-\mathrm{NO}_{3}{ }^{-}$plus exchangeable $\mathrm{NH}_{4}{ }^{+}$[69]. It is usually the case that pea and lentil as the previous crops before durum wheat in a rotation provide a significant amount of residual soil $\mathrm{N}$. In a rotation study comparing monoculture and diversified cropping systems, it was found that the amount of soil available $\mathrm{N}\left(\mathrm{NO}_{3}+\mathrm{NH}_{4}\right)$ at spring planting time was $50.4 \mathrm{~kg} \mathrm{ha}^{-1}$ in the preceding lentil treatments, which was $44 \%$ higher compared with preceding barley or flax treatments [43]. The largest increase in soil $\mathrm{N}$ between the preceding crop management practices was in the top 0-0.6 $\mathrm{m}$ soil layer, with little or no difference below the $0.6 \mathrm{~m}$ soil depth.

During the seven- to nine-month period from crop harvest the previous fall to the planting durum wheat the following spring, the soil $\mathrm{N}$ status can change dramatically, due to mineralization of soil organic matter and crop straw and root decomposition [75]. These processes result in additional $\mathrm{N}$ to the soil $\mathrm{N}$ pools, even though $\mathrm{N}$ leaching may occur in some cases [76]. Studies in southwestern 
Saskatchewan have shown that the $\mathrm{N}$ gained during this period may account for $25 \%$ of the total amounts of soil $\mathrm{N}$ that are available by planting time of the following durum crop [43]. A net soil $\mathrm{N}$ gain during the postharvest period ultimately contributes to the total amount of $\mathrm{N}$ available to the following crop [77]. Adequate soil moisture is required to stimulate soil microbial activity that is essential for soil $\mathrm{N}$ mineralization and accumulation [78].

\subsubsection{Soil Microbiome}

The inclusion of annual pulses in rotation with durum wheat stimulates the soil microbial community function that provides feedback to the crop. Some recent studies conducted in the major durum wheat-growing areas in western Canada have shown that pulse plants can modify soil microbial environments. The positive feedback can carry over to affect the subsequent cereal crops [79-81]. The feedback mechanism contributes to the strong "rotational effect" [81-83] in which the subsequent wheat is benefited (Section 5 below for detailed discussion on the subject: soil microbiome).

Due to improved soil water availability and soil $\mathrm{N}$ status, and enhanced soil microbial environments by the inclusion of annual pulses in rotation with durum wheat, the diversified cropping systems have been shown to enhance systems productivity $[43,57]$ and economics [84], increase water use efficiency (WUE, i.e., $\mathrm{kg}$ grain yield per $\mathrm{mm}$ of available water) [68] and soil nutrient supply powers [78,85], and enhance environmental sustainability [86]. Additionally, the diversified cropping systems suppressed pathogenic fungal endophytes [87] and enriched soil biological properties [88,89].

Contrasting with the pulse effects on durum wheat in rotation, the effect of preceding oilseeds, such as canola and flax (Linum usitatissimum L.), on durum wheat productivity, is inconsistent in the literature and varies with many factors. For example, a three-year rotational study on silt loam soil in southwestern Saskatchewan showed that durum wheat increased grain yields by $5 \%$ and grain protein concentration by $6 \%$ when following canola and mustard than following spring wheat, while the durum wheat increased grain yield by $7 \%$ and protein concentration by $11 \%$ when following pulse crops, relative to after spring wheat [9]. In Orthic Black Chernozemic soils in southern Manitoba, which is outside the durum wheat area, wheat-flax-durum and canola-flax-durum rotations repeated for three cycles showed that canola-flax as preceding crops led to greater subsequent durum wheat yield than wheat-flax as the previous crops in only one out of six site-years [90]. Many factors are involved in the inconsistent rotational effects, such as soil type [61] and agronomic practices [91]. For example, weed management practices affect soil chemical properties (such as denitrification and denitrifier community structure), thereby affecting the rotational outcomes of durum wheat [91]. These results show that the outcomes of substituting conventional summerfallow with annual pulses or small-seeded oilseeds for durum wheat productivity may depend on soil type, moisture availability, and agronomic practices.

\subsection{Management of Soil Fertility}

Efficient fertilizer management in durum wheat production involves the interactive effects of fertilizer rate, time of application, and the source and placement of fertilizers. Each of these elements is critical to optimize crop yield and quality, while minimizing the loss of nutrients to the environment.

\subsubsection{Nitrogen and Phosphorus}

One of the key components in wheat cultivation is nutrient management. Nitrogen is the most important nutrient in wheat, and improving $\mathrm{N}$ use efficiency (NUE) can increase grain yield per unit of fertilizer input [92,93]. Also, higher NUE will lower the carbon footprints (i.e., total greenhouse gas emissions per unit ( $\mathrm{kg}$ or $\mathrm{t}$ ) of grain) in the crop production (Figure 9), as $\mathrm{N}$ fertilizer applied to the crop contributes $36 \%$ to $52 \%$ of the total greenhouse gas emissions associated with various inputs in the production of the crop [50].

In agronomic research, a number of terms have been used to assess crop NUE: $\mathrm{N}$ uptake efficiency (NUpE), which is the efficiency of absorption or uptake of supplied $\mathrm{N}$, and $\mathrm{N}$ utilization efficiency 
(NUtE), which is the efficiency of assimilation and remobilization of plant $\mathrm{N}$ to grain sinks [94]. The simplest definition of crop NUE is the grain yield (Y) or grain $\mathrm{N}$ content (GN), divided by either fertilizer $N(F N)$, or (FN + soil test $N(S N))$, or (FN + SN + estimated growing season net $\mathrm{N}$ mineralization (Nmin)). Each of the NUE terms has its own merits. However, from cropping system perspective, we suggest the NUE $=\mathrm{Y} /(\mathrm{FN}+\mathrm{SN}+\mathrm{Nmin})$ as most preferred because it takes consideration of soil residual $\mathrm{N}$ and potential mineralizable $\mathrm{N}$ in addition to the $\mathrm{N}$ from nitrogen fertilizer.

Balanced fertilization has been shown to play a vital role in enhancing input use efficiency $[95,96]$. $\mathrm{N}$ fertilizer required for optimizing crop yield and quality is a function of the difference between crop $\mathrm{N}$ demand and the amount of $\mathrm{N}$ supplied by the soil. In deciding an appropriate rate of $\mathrm{N}$ fertilization, soil tests are used to quantify the amounts.

Also, soil nutrients available at the planting time and potential nutrient gains through mineralization during the cropping season are considered for fertilizer recommendations. The $\mathrm{N}$ supply to crops for up to two years after the final application still has an effect on the residual soil $\mathrm{N}$ that affects fertilizer $\mathrm{N}$ use efficiency [97]. It is of importance that $\mathrm{N}$ fertilizer rates are adjusted based on the soil residual $\mathrm{N}$ and the potential of $\mathrm{N}$ mineralization of the preceding crops to minimize the potential for $\mathrm{N}$ losses [78].

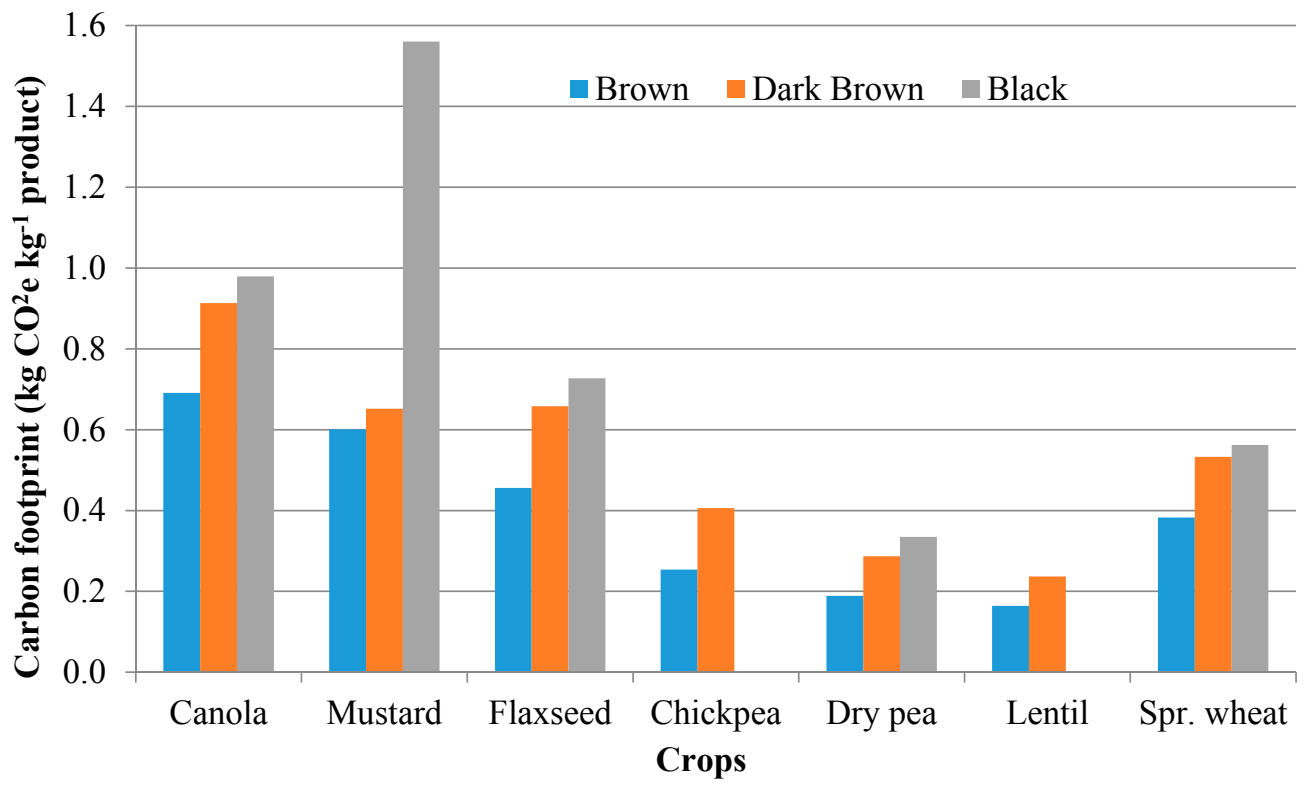

Figure 9. The carbon footprint of durum wheat preceded by different crops in a rotation; they were significant at the $p<0.01$ level across the treatments (adapted from Gan et al. [86]).

Studies have shown that hard red spring wheat grown on the Canadian prairie can have NUE averaging $10.9 \mathrm{~kg}$ grain $\mathrm{kg}^{-1}$ available $\mathrm{N}$ or $0.3 \mathrm{~kg}$ grain $\mathrm{N} \mathrm{kg}^{-1}$ available $\mathrm{N}$ (where available $\mathrm{N}$ includes fertilizer $\mathrm{N}$, soil test $\mathrm{N}$, and season net $\mathrm{N}$ mineralization) [96]. However, there is no quantitative data on durum wheat NUE from Canadian prairie. It is common that $\mathrm{N}$ fertilizer use efficiency in cereals can be enhanced by seed-placement of $\mathrm{N}$, but seed-placement of urea in close proximity to germinating seeds can cause seedling injury at a rate as low as $28 \mathrm{~kg} \mathrm{~N} \mathrm{ha}^{-1}$ [98]. This challenge may be alleviated via use of polymer-coated urea or urease inhibitors that reduce hydrolysis of urea to $\mathrm{NH}_{3}[99,100]$. However, there is no information available whether the application of urea-coated fertilizers can improve the performance in durum wheat. Durum wheat requires a large amount of $\mathrm{N}$ supply to optimize grain yield and at the same time maintain quality traits such as protein and micronutrition [46,101]. Increasing $\mathrm{N}$ fertilizer rates often increases durum wheat yields. The magnitude of the yield increases varies with environmental conditions, soil type and tillage system, and the form of fertilizer and timing of application [101,102]. New durum wheat cultivars are released 
every year on the Canadian prairie. Cultivar-specific fertilization is necessary to optimize fertilizer use efficiency $[102,103]$. Although results from some of the $\mathrm{N}$ rate studies can be applied to a larger set of cultivars $[46,104,105]$, we must recognize the possibility of a cultivar by $\mathrm{N}$ rate interaction that affects grain yield and NUE.

Unlike $\mathrm{N}$ fertilizer, the effect of $\mathrm{P}$ fertilizer rates and $\mathrm{P}$ sources on durum wheat grain yield is rarely significant $[101,106,107]$; this is because the soils in the conventional cropping areas on the Canadian prairie are normally rich in $\mathrm{P}$, a phenomenon similar to potassium $(\mathrm{K})$ where all soils on the prairie contained $\mathrm{K}$ levels mostly in excess of what is considered a critical level for obtaining a yield response [108]. However, when P level in the soil is smaller than $10 \mathrm{~kg} \mathrm{ha}^{-1}$, an addition of $P$ fertilizers usually has a positive effect on durum wheat yield on the Brown and Dark Brown soils [101,109]. In some cases, increased fertilization with monoammonium phosphate to durum wheat could reduce soil $\mathrm{pH}$ and enhance root proliferation [110], but may reduce grain quality [109] or modify the micronutrient profile in the durum grain [111]. There exists a complex interplay between multinutrient dynamics within the rhizosphere of a durum wheat crop. The potential effect of phosphorus nutrient on durum wheat productivity interacts with several factors, including tillage and rotation [112,113], preceding crops before durum wheat in a rotation [13], and environmental conditions [101].

\subsubsection{Fertilizer Management and Environmental Footprint}

In the production of field crops, it has been a challenge to increase crop yield without causing a negative impact on the environment $[50,114]$. The way fertilizers are applied to a durum wheat crop may have a significant impact on environmental footprints. In a three-year rotation study conducted on an Aridic Haploboroll soil and a Vertic Cryoboroll soil in western Canada, in which durum wheat was the Year-3 crop in the rotation, researchers found that greenhouse gas (GHG) emissions from the production, transport, storage, and delivery of $\mathrm{N}$ fertilizers account for $36 \%$ of the total emissions, and application of $\mathrm{N}$ fertilizers accounts for additional $26 \%$ of total emissions [86]. The activities related to $\mathrm{N}$ fertilizer account for about $62 \%$ of total GHG emission in durum wheat production.

Due to the significant contribution of $\mathrm{N}$ fertilization to GHG emission, any approach to reduce inorganic $\mathrm{N}$ fertilization or enhance the NUE in durum wheat cropping will be effective to minimize GHG emissions. Nitrogen fertilizers in soil are highly dynamic, so frequent diagnosis of soil $\mathrm{N}$ status is required [19]. In reality, only $22 \%$ of farmers on the Canadian prairies tested their soil each year, and the majority of producers do not test their soils for nutrient decisions [115]. We suggest that adoption of an accurate soil fertility testing approach could be considered as an effective approach to enhance nutrient use efficiencies and minimize nutrient losses.

Further, N status varies within a field [19]. Site-specific and/or timing-specific application of $\mathrm{N}$ fertilizer can result in a precise match between $\mathrm{N}$ application and plant $\mathrm{N}$ requirements. It will avoid unnecessary overapplication of $\mathrm{N}$ fertilizer that causes $\mathrm{N}$ loss or $\mathrm{N}_{2} \mathrm{O}$ emissions [19]. Therefore, we suggest that precise $\mathrm{N}$ rate application across a field within a farm to be considered the priority for further studies, to enhance NUE and mitigate GHG emissions in durum wheat production. Various precision agriculture tools and algorithms are available, which use map- or sensor-based approaches that support the site-specific detection and correction of nutrient deficiencies. The precision agriculture approaches may be able to help implement site-specific management in application of crop inputs in variable rates, either remotely or in real-time [116]. Some of these new technologies, specifically for durum wheat production, have been investigated in Arizona, USA [117]. However, no research has been done on durum wheat under the Canadian prairie conditions. We suggest that year-to-year variation and site-to-site variation in soil nutrient should be a prioritized issue for researchers to address in which precision agriculture should be adopted in durum wheat production. 


\subsection{Management to Minimize Grain Cadmium}

Levels of the heavy metal cadmium (Cd) in food products are a safety concern [118]. Durum wheat crop has a propensity to accumulate $\mathrm{Cd}$ in the grain. Thus, the $\mathrm{Cd}$ content in durum grain is naturally higher than in hexaploid wheat. Therefore, management practices to reduce $\mathrm{Cd}$ are a priority in durum wheat production.

The uptake of $\mathrm{Cd}$ in plants varies with plant genotypes and chemical composition in the soil. The bioavailable $\mathrm{Cd}$ content in durum wheat grains is a function of the presence of high amounts of carbonates, Fe-oxyhydroxides, clay content, and the nature of silicate clay mineralogy in the soils [119]. During the durum wheat vegetative growth period, $\mathrm{Cd}$ can be transported from soil to roots and then to grain sinks through the xylem-to-phloem pathway in the stem. Agronomic management practices can be used to manipulate the $\mathrm{Cd}$ concentration in the grain, such as through partitioning photosynthetic assimilates [120] and optimizing planting date. Use of conservation tillage practices can reduce $\mathrm{Cd}$ contents in the durum wheat grains, as the practice may be able to modify the magnitude of the chemical translocation from the root to the shoot [90]. Increased transpiration is associated with increased Cd content in some genotypes of durum wheat [121]. Increased P application can increase $\mathrm{Cd}$ concentration in the grain, due to competition between $\mathrm{Cd}$ and $\mathrm{Zn}$ absorption, an antagonistic effect of $\mathrm{Zn}$ on $\mathrm{Cd}$ for root uptake and distribution within the plant [122]. Thus, an optimal P fertilization, possibly in combination with $\mathrm{Zn}$ application, may serve as an important agronomic strategy for decreasing $\mathrm{Cd}$ concentration in crops [123]. However, the outcomes of these effects vary with soil type, environmental conditions, and plant genotypes [124].

Cadmium uptake in durum wheat varies with plant genotype and soil $\mathrm{Cd}$ concentrations on the Canadian prairie. In a 3-year field study conducted on two soils of southwestern Saskatchewan, Selles et al. [101] evaluated the impact of phosphate fertilizer containing varying concentrations of $\mathrm{Cd}$ on grain yield and found that the variability in $\mathrm{Cd}$ concentration in durum wheat was attributed to both genotype (accounting for $41 \%$ of the variability) and environment ( $29 \%$ of the variability). The most important strategy to reduce $C d$ accumulation in durum wheat is reported to use the $C d u 1$ gene, which conditions the low grain cadmium phenotype [125]. These studies demonstrate that durum wheat genetics is the key to control the Cd properties in the grain, while soil factors such as soil organic carbon and $\mathrm{pH}$ influence the uptake of $\mathrm{Cd}$ by the durum wheat plants [126].

\subsection{Optimizing Feedback Benefits from Soil Microbiomes}

A significant innovation in the durum wheat agronomy on the Canadian prairie is the discovery of the association between durum wheat productivity and soil microbial community. A number of studies have shown that, in pulse-durum rotations, the preceding pulse crops influence microbial community in the soil, the root, and in the rhizosphere of the subsequent durum wheat $[80,81,127]$. The stimulation of soil microbial community with preceding pulses promotes the stand establishment, root growth, and grain yield of the subsequent durum wheat $[80,81,128]$. In many cases, the yield of durum wheat is associated with the composition of the endospheric bacterial community in the wheat root [80]. A high richness of root endospheric Actinobacteria and Acidobacteria and a low amount of endospheric Firmicutes often lead to a greater durum wheat grain yield. This may partly explain the so-called "rotational effect" in crop production.

Many agronomic practices influence the association between soil microbial community activities and the enhancement of durum wheat productivity. Below, we highlight some of the key agronomic factors influencing the durum plant-soil microbiome association.

\subsubsection{Crop Species and Genotypes}

Crop species differ in affecting the soil microbiomes in the soil and the roots of the subsequent durum wheat $[80,129]$. For example, pea and chickpea differ in their capacity to influence associated rhizobacterial community composition. Pea is more closely associated with the rhizobacterial 
communities than chickpea, that increases aboveground growth in subsequent durum wheat when abundant precipitation is available. In pea, abundance of several rhizobacteria is significantly linked with the growth of durum plant shoot and roots. Also, plant genotypes differ in influencing type and frequency of soil microbiomes $[63,87,130]$. These results partly explain the large rotation effects of pulse crop's selection of rhizobacterial communities on durum wheat growth.

The choice of genotypes in the previous pulses can change the rhizospheric fungal community structure in wheat crops grown the following year $[79,131,132]$. This is largely driven by host's secondary phytochemical activities $[88,133]$. The magnitude of the effect varies with genotypes and the effect can vary with year. These results show that selective use of host pulse species and genotypes can help promote beneficial microbial environments in soils through the regulation of soilborne endophytes, with the production of phytochemicals in the plant roots.

Research on the Canadian prairie has suggested that it is imperative for crop breeders to include plant-microbial partnerships as an additional focus for breeding programs to deliver efficient genotypes for sustainable agricultural systems [134]. Beneficial soil fungi present a great opportunity to make global agriculture more efficient, sustainable, and productive $[135,136]$. Therefore, it is critical that crop genotypes be assessed for symbiotic potential, that crop genomes are mapped to uncover the traits associated with mycorrhizal partnership, and that these traits are linked to crop yield and nutritional value of the grain.

\subsubsection{Pulse Termination}

Time of crop harvest affects postharvest soil water and residual $\mathrm{N}$ [13], as well as soil microbiomes [81]. These effects may have significant impacts on soil health and the performance of the crops to be grown the following year. In pulse-durum wheat rotation systems, the time-to-maturity of the pulse affects these soil variables [137]. An early termination of preceding pulse crops produces higher durum wheat yield than a late termination, due to the termination timing affecting the composition and richness of root endosphere bacteria community in the durum root [80]. Soil moisture often plays a significant role in capturing those opportunities. For example, dry pea matures about 40 to 70 days earlier than chickpea under the southwestern Saskatchewan conditions; this influences the abundance of endophytic fungal antagonist hosted by the following durum wheat. In a 3-year field study, it was found that there were more fungal antagonist after early-maturing pea than after the long-season chickpea [127]. The endophytic fungal antagonists in the pea roots may function as root disease protectors for their host. As a result, the durum wheat with an abundance of the functional group of endophytic fungal antagonists produced significantly higher grain yield than the control [127].

\subsubsection{Soil N Effect}

Since soil $\mathrm{N}$ fertilization stimulates the activity of the soil bacterial species, which impacts the performance of the denitrification processes in the soil [138], the status of soil $\mathrm{N}$ affects the microbial communities in the roots of durum wheat. Those soil bacterial denitrifiers can alter the processes of nitrification and denitrification directly or indirectly in response to the soil $\mathrm{N}$ status. These effects can alter the soil $\mathrm{N}$ availability and greenhouse gas emissions in the subsequent wheat crop. Raising the soil $\mathrm{N}$ fertility modifies the diversity and composition of nitrite reductase (nirK and nirS) and nitrous oxide reductase (nosZ) gene-carrying denitrifying bacterial communities. In practice, a high $\mathrm{N}$ fertilizer rate will increase the risk of $\mathrm{N}_{2} \mathrm{O}$ emissions, mainly by promoting the proliferation of the mostly adaptive $\mathrm{N}_{2} \mathrm{O}$-producing over the less adaptive $\mathrm{N}_{2} \mathrm{O}$-reducing bacterial community.

\subsubsection{Pesticide Use}

Timely use of fungicides, such as chlorothalonil, pyraclostrobin, and boscalid, are necessary to suppress foliar diseases in some crops [139]. While fungicides are meant to target specific fungal pathogens, they impact non-target organisms, and may alter soil microbial community structure [131]. In a 2-year chickpea-durum wheat rotation study, the application of some fungicides (primarily 
chlorothalonil, pyraclostrobin, or boscalid, commonly used to control Ascochyta blight in pulses) increased the relative abundance of Fusarium graminearum in the seminal roots of a subsequent durum crop in one of the two years [131,137]. The chemicals used for disease control affects the diversity of nitrogenase iron protein $(n i f \mathrm{H})$ gene sequences in the rhizosphere by modifying host plant physiology [140]. Systemic non-target effects of phytoprotection on the diversity in plant rhizosphere suggest the possibility of manipulating soil microbiomes to promote the growth and yield of the crops grown in the pulse-durum rotation systems.

\section{Identification of Constraints to Durum Wheat Production}

Constraints to durum wheat production on the Canadian prairie can be classified as having biotic or abiotic causes. Various pathogens and insects have become endemic, which can infect or feed upon leaves, stems, roots, and kernels of Canadian durum wheat [141,142]. The main diseases categorized by the Prairie Recommending Committee of Wheat Rye and Triticale (PRCWRT) include Fusarium head blight (FHB) Fusarium graminearum Schwabe (telomorph: Gibberella zeae Schw. (Petch)), leaf rust (Puccinia triticina Eriks.), stem rust (P. graminis Pers.:Pers. f.sp. tritici Eriks. \& E. Henn.), yellow rust (Puccinia striiformis f. tritici Eriks.), and common bunt (Tilletia laevis Kühn in Rabenh., and T. tritici (Bjerk.) G. Wint. in Rabenh.).

FHB reduces yield and the end-use quality of durum wheat. The fungus can produce mycotoxins, particularly a trichothecene deoxynivalenol (DON) [143], which are hazardous to humans and other animals. Kernels damaged by FHB are called Fusarium-damaged kernels, which are distinguished as thin or shrunken chalk-like grains often with a white to pinkish fibrous-mold appearance.

Under moist conditions, leaf spotting and kernel diseases, red smudge, and black point increase on durum wheat, causing yield and end-use quality losses [144-146]. Leaf spotting diseases of wheat occur in all regions to varying degree. The causal pathogens include Pyrenophora tritici-repentis (Died.) Drechs. (anamorph Drechslera tritici-repentis (Died.) Shoemaker), Mycosphaerella graminicola (Fuckel) J. Schröt. in Cohn, Krypt.-Fl. Schlesien, (anamorph: Zymoseptoria tritici (Desm.) Quaedvlieg \& Crous 2011, formerly Septoria tritici Berk. \& M.A. Curtis) and Phaeosphaeria nordorum (E. Müller) Hedjaroude (anamorph Stagonospora nodorum (Berk.) Castellani \& E.G. Germano). Tan spot, caused by P. tritici-repentis, is one of the most important leaf diseases in durum wheat. Under field conditions, short stature genotypes had either equal or greater disease than tall genotypes. Plant height might affect tan spot development in durum wheat under conditions prevalent in southern Saskatchewan, and that this is probably mediated by canopy density [147]. Under the dryland environment and management in southern Saskatchewan, leaf spotting diseases generally have a small effect on yield, kernel weight, test weight, and protein concentration [148]. The pathogen that causes tan spot can also infect the kernel, causing red smudge which reduced durum wheat emergence, growth, and seedling vigor [145]. Since red smudge kernels can affect semolina color, it is also a degrading factor leading to economic loss.

Early foliar application of fungicides might increase dark kernel discoloration and grain downgrading (which reduces selling price for farmers), although fungicide use on durum wheat is considered as a strategy to improve productivity [145]. Fungicide applications between stem elongation and flag emergence could increase black point infection, even though it was associated with an increase in kernel mass [149], whereas these same fungicide applications at, or after, head emergence could reduce the incidence of black point, but fungicide application did not interfere with seeding rates, choice of cultivars, or the rate of $\mathrm{N}$ fertilization [103].

Durum wheat grown in western Canada faces market-grade losses due to insect damage. The wheat stem sawfly caused by Cephus cinctus, Norton Hymenoptera: Cephidae, is one of the most damaging insect pests, causing significant yield losses [150]. Sawfly larvae hatch from eggs deposited inside the stem, and their subsequent feeding damages vascular tissue, reducing photosynthetic capacity and grain yields [37], and expression of solid pith provides reduction in stem cutting [33,150].

Since the mid 1980s, orange wheat blossom midge (OWBM) has become an important insect pest of wheats in western Canada, commonly known as midge [151,152]. It was first detected as early as 
1901 in western Canada. Annual losses in grain yield and end-use suitability due to OWBM midge were estimated to be $\$ 60$ million CAD prior to the commercial production of wheat varieties carrying the OWBM resistance gene Sm1 (Ian Wise, unpublished data).

\section{Genetic Enhancement}

\subsection{Genetic Gain}

Efforts have been taken to improve grain yield, quality, disease and insect resistance, and the various agronomic traits in Canadian durum wheat cultivars over the past half-century. Conventional selection methods, along with biotech-based high throughput techniques and doubled haploid techniques, have been used in durum wheat breeding $[125,153,154]$. The outcome of the genetic enhancement efforts registered some significant gains [154,155]. Transcend [156] is the first doubled haploid (DH) durum wheat cultivar released in North America. However, the time to develop a conventional and a DH durum wheat cultivar likely uses the same number of years from cross to registration, because of re-testing of $\mathrm{DH}$ lines under field conditions. To reduce the breeding cycle and increase genetic gain, durum breeders use contra-season nurseries in the Southern Hemisphere to grow and select in Canadian winter months.

Using historical data of Durum Wheat Cooperative Tests that were conducted across the prairie ecozones from 1963 to 1990, McCaig and Clarke [155] found an increase of durum wheat grain yield, about $0.81 \%$ per year, relative to the check Hercules. In a similar study, Clarke et al. [154] found that genetic gain in grain yield of durum wheat between 1947 and 2009 increased by $0.70 \%$ per year relative to the check Hercules. With the latest data of Durum Wheat Cooperative Tests on registered durum cultivars in Canada, we analyzed the genetic gain of durum wheat yield over the period 1963 to 2017, relative to the check Strongfield (Figure 10). The upward trend in grain yield did not appear uniform, and there was an acceleration starting in the mid-1990s. The linear regression revealed a yield increase of $0.48 \%$ per year from 1963 to 1994, and an increase of $0.81 \%$ per year from 1995 to 2017. The two slopes of the regressions differed significantly at $p<0.001$. The significant genetic yield gain can be attributed to the increased long-term funding via Wheat Research Check-Off fund (started in 1994) which has facilitated processing large populations of strategic crosses, application of new breeding technologies, mechanization and computerization, and career opportunities for support staff.

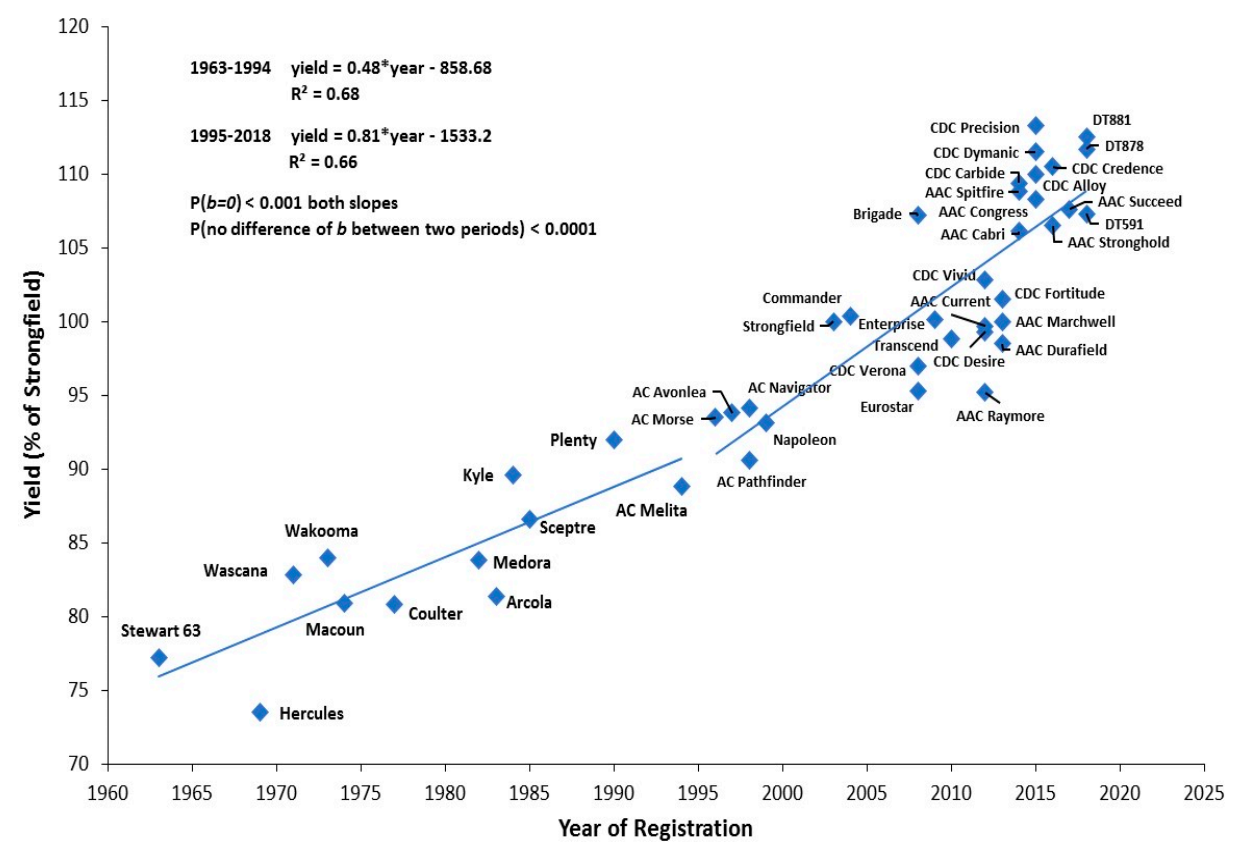

Figure 10. Grain yield (relative to the latest check cultivar AC Strongfield) and year of registration of Canadian durum wheat cultivars. Data are analyzed using a similar method described by Clarke et al. (2010). 
With the current cultivar registration policies in Canada, a new cultivar of durum wheat must have improvements in grain yield relative to the check cultivars while maintaining protein concentration similar to the mean of these check cultivars. However, grain yield and grain protein concentration are typically negatively correlated $[154,157]$. To overcome this negative relationship, simultaneous selection for grain yield and protein in early generations through the application of NIR technology has resulted in shifting this negative correlation [157]. The genetic gain in grain yield was achieved without a significant downward shift in grain protein concentration in durum wheat (Figure 11).

The data from the SCIC indicate that on-farm productivity increased by $70.2 \mathrm{~kg} \mathrm{ha}^{-1}$ per year during 2001-2017 years on farmers' fields (Figure 3). In this review, we were unable to discern yield gain due to genetic enhancement from agronomic improvements due to limited data sources, but it is generally considered to be attributable more or less equally.

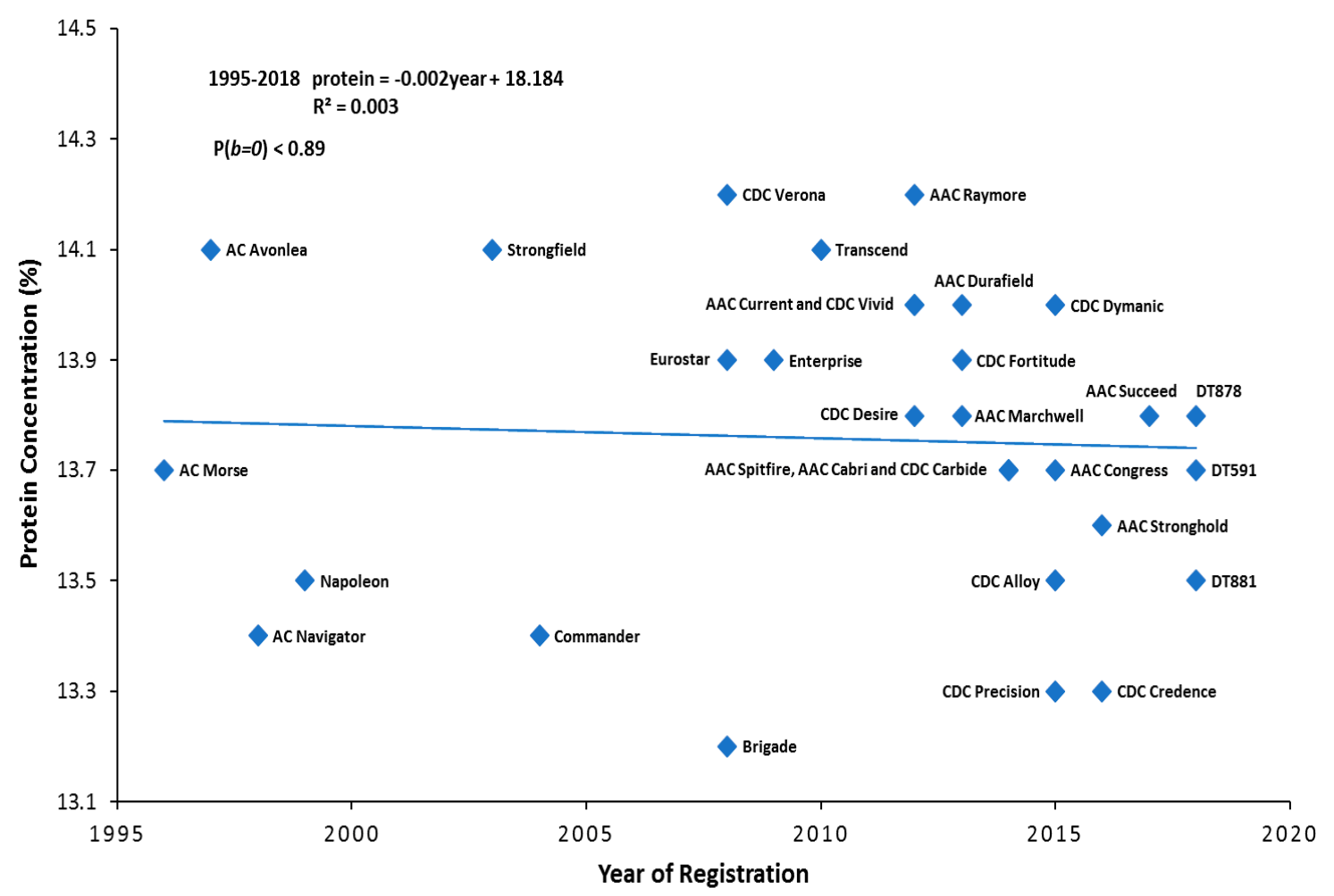

Figure 11. Grain protein concentration and year of registration of Canadian durum wheat cultivars. Data are analyzed using a similar method described by Clarke et al. (2010).

\subsection{Historical Change of Durum Wheat Cultivars}

Several histories have been written on cultivar development of Canadian durum wheat $[154,158]$. The present review will focus primarily on the new cultivars registered during the past ten years. Historically, the durum wheat cultivars Wascana and Wakooma were the predominant genotypes occupying over $70 \%$ of the durum area before 1987 [158]. A subsequent, significant change occurred with the release of the cultivar Kyle [159], which became the dominant cultivar by 1991, and it accounted for about $80 \%$ of the total durum wheat seeded area in western Canada [158]. Since Kyle had improvements in grain yield, standability, and held grain color in the presence of pre-harvest moisture, it was a challenge to surpass. Following the genetic enhancement shown in Kyle, a number of new durum wheat cultivars were developed, including AC Avonlea [35], which became the most abundantly grown cultivar from 2005 to 2006, because of its higher grain yield and protein concentration (Figure 12). AC Avonlea was quickly replaced by the first low Cd uptake cultivar Strongfield which combined the traits high grain yield, high grain protein concentration, good standability, and strong gluten. For the period 2007 to 2015, Strongfield was the most widely grown 
cultivar, occupying from $40 \%$ to $80 \%$ of the seeded area. Over the years, the dynamic change in durum wheat cultivars occurred mostly between preceding dominant cultivars and the ones with various phenotypic traits. In 2017, three cultivars accounted for more than $70 \%$ of Canadian durum wheat seeded area: Transcend, about 43\%; Strongfield at 16\%; and Brigade [160] at 14\%. Transcend and Brigade both have lower FHB and DON. More recently, a number of varieties have been released with higher grain yield than Strongfield (Table 1).

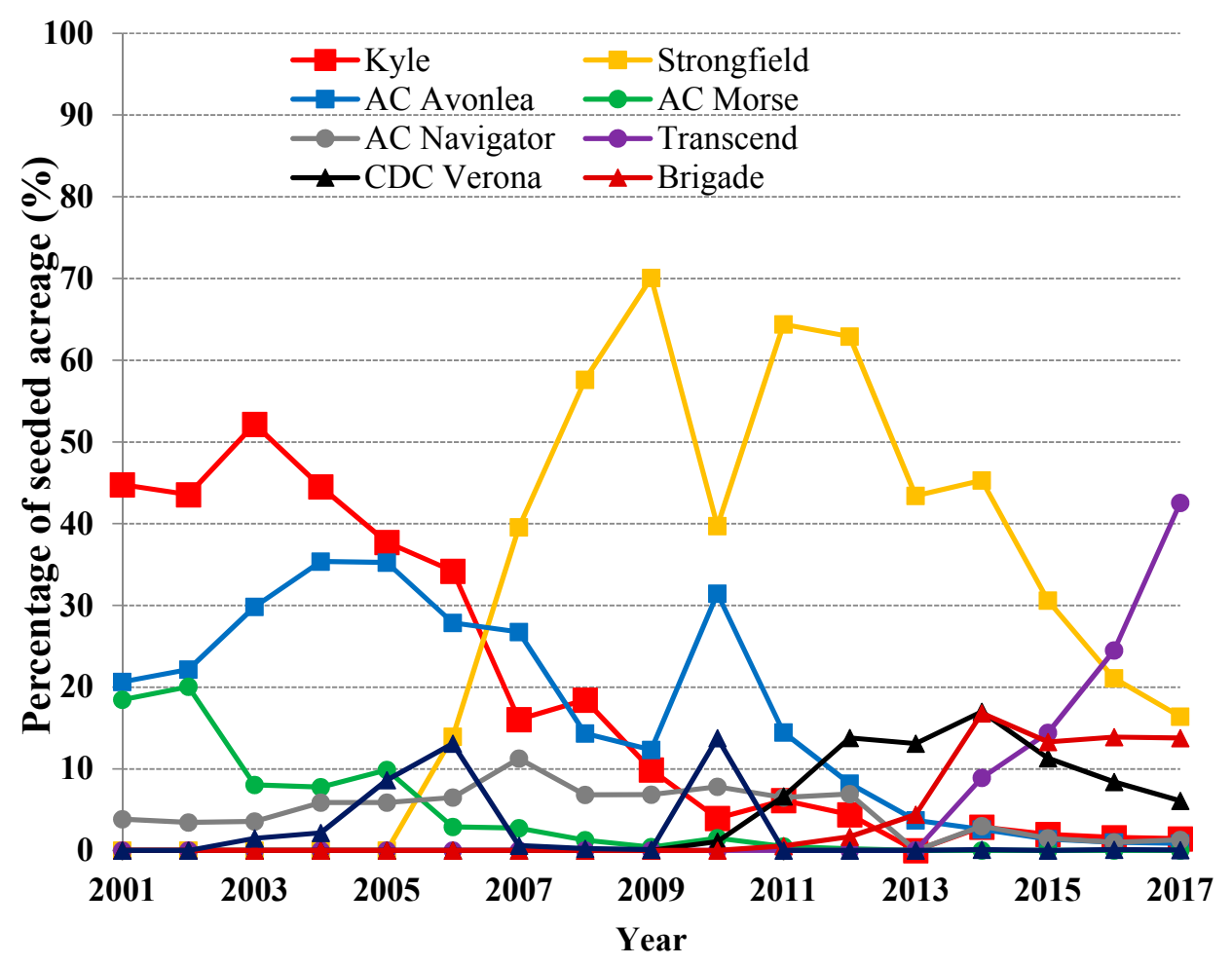

Figure 12. Percentage of seeded areas by the major Canadian durum wheat cultivars during 2001-2017 (Source: Provincial crop insurance data compiled with Canadian Grain Commission). 
Table 1. Major durum wheat cultivars released since 2010 in Canada, and their yields and protein deviation relative to the check cultivar Strongfield.

\begin{tabular}{|c|c|c|c|c|c|}
\hline Name & $\begin{array}{l}\text { Grain Yield \% Increase } \\
\text { over Strongfield }^{1}\end{array}$ & Protein Dev Strongfield ${ }^{1}$ & Key Traits & Released & Reference \\
\hline Transcend & 3.1 & -0.3 & Improved FHB resistance MS * & 2010 & [156] \\
\hline CDC Desire & 1.0 & -0.2 & High grain pigment & 2012 & [161] \\
\hline CDC Vivid & 3.0 & -0.3 & High grain pigment, strong straw & 2012 & [162] \\
\hline AAC Current & 1.0 & 0.0 & High test weight & 2012 & [163] \\
\hline AAC Raymore & -5.0 & 0.2 & Solid stem, resistant to sawfly & 2012 & [164] \\
\hline CDC Fortitude & 4.0 & -0.2 & Solid stem, resistant to sawfly & 2013 & [165] \\
\hline AAC Durafield & 2.0 & -0.2 & Semolina yield & 2013 & [166] \\
\hline AAC Marchwell VB & -1.0 & -0.1 & Midge tolerant & 2013 & [167] \\
\hline CDC Carbide VB & 7.0 & -0.2 & Midge tolerant & 2014 & [168] \\
\hline AAC Cabri & 5.0 & -0.3 & Solid stem, resistant to sawfly & 2014 & [169] \\
\hline AAC Spitfire & 9.0 & -0.5 & High pigment, strong straw & 2014 & [170] \\
\hline CDC Precision & 10.0 & -0.6 & High test weight & 2015 & [171] \\
\hline CDC Dynamic & 7.0 & 0.0 & High test weight & 2015 & [172] \\
\hline CDC Alloy & 10.0 & -0.4 & High test weight & 2015 & [173] \\
\hline AAC Congress & 9.0 & -0.5 & Semolina yield & 2015 & [174] \\
\hline CDC Credence & 6.0 & -0.7 & Improved FHB resistance $(\mathrm{MS} *)$ & 2016 & $\mathrm{~N} / \mathrm{A}$ \\
\hline AAC Stronghold & 4.0 & -0.4 & Very strong straw, solid stem, resistant to sawfly & 2016 & $\mathrm{~N} / \mathrm{A}$ \\
\hline DT587 & 8.0 & -0.5 & $\mathrm{~N} / \mathrm{A}$ & 2017 & $\mathrm{~N} / \mathrm{A}$ \\
\hline AAC Succeed VB & 4.0 & -0.1 & Midge tolerant & 2017 & $\mathrm{~N} / \mathrm{A}$ \\
\hline DT591 & 6.1 & -0.2 & Imidazolinone tolerance & 2018 & $\mathrm{~N} / \mathrm{A}$ \\
\hline DT878 & 9.5 & -0.2 & Solid stem, resistant to sawfly & 2018 & $\mathrm{~N} / \mathrm{A}$ \\
\hline DT881 & 9.9 & -0.3 & Strong straw & 2018 & $\mathrm{~N} / \mathrm{A}$ \\
\hline
\end{tabular}

1 Source: Varieties of Grain Crops 2018, Saskatchewan and Prairie Recommending Committee of Wheat Rye and Triticale (PRCWRT). MS *, Fusarium head blight index on average is at a lower level tending towards an intermediate resistance class; N/A, not available; VB is varietal blend of $90 \% \mathrm{Sm} 1$ cultivar and $10 \%$ non-Sm1 cultivar as refuge for midge. 


\subsection{Breeding for Resistance to Abiotic Stresses}

Sprout damage in durum wheat is caused by preharvest sprouting (PHS) that occurs when harvest time coincides with high humidity in the field, due to untimely rainfall. It reduces seed quality and causes a loss of starch gel viscosity, which negatively affects pasta quality. Severe losses were reported in some years $[175,176]$. Durum wheat cultivars can benefit from having some level of seed dormancy to help reduce seed damage and lower grain quality caused by PHS during wet harvesting conditions. Clarke et al. [175] and DePauw et al. [177] reviewed the breeding methods employed by Canadian breeders to incorporated genetic resistance to PHS in various wheat market classes. This information can serve as a guide to Canadian breeders or breeders in other nations. Knox et al. [176] demonstrated the need to apply multiple methods of measurement over multiple durations of germination to maximize understanding of transgressive segregation and quantitative trait loci (QTL) for PHS. A number of PHS resistance loci were identified, many of which overlap with loci found in hexaploid wheat; these loci are considered foundational to the expression and further enhancement of the trait. Singh et al. [178] described useful parental material to enhance durum PHS resistance along with high grain yield. Chao et al. [179] identified two quantitative trait loci (QTL) regions affecting seed dormancy, which could be useful for improving PHS tolerance in wheat.

The heavy metal $\mathrm{Cd}$ is toxic to humans and can lead to kidney damage [118]. A maximum $\mathrm{Cd}$ level of $200 \mathrm{ng} \mathrm{g}^{-1}$ is acceptable in cereal grains [180]. The majority of genetic variation for Cd concentration in durum wheat is explained by a single dominant gene Cdu1 [181], which has a high heritability and, therefore, has been a prime target for marker-assisted selection [154]. All cultivars, subsequent to the release of Strongfield in 2003, have the low cadmium uptake trait. Breeding efforts have shown that the level of $\mathrm{Cd}$ content in durum wheat can be successfully reduced without a yield penalty (Table 1).

\subsection{Breeding for Resistance to Biotic Stresses}

Breeding resistance to pathogens and insects is still among the top priorities for Canadian durum wheat besides grain yield and end-use quality. As of 2018, all durum cultivars are resistant to prevalent races of leaf rust, and resistant or moderately resistant to prevalent races of stem rust, stripe rust, and common bunt, except AAC Stronghold, which has intermediate resistance to common bunt, and AAC Succeed which has intermediate resistance to stripe rust [182].

One of the most important current challenges in durum wheat is FHB [183]. Although breeding for FHB resistance in durum wheat began in the early 2000s, where some genetic variability within the Canadian durum genepool for FHB symptoms was detected, no cultivars have been released which have an intermediate level of resistance. The cultivars Brigade and Transcend expressed lower levels of FHB symptoms and DON. Several QTL for FHB resistance have been identified in wild relatives of durum wheat [184,185], and efforts are ongoing to use both genomic and phenotyping approaches to bring them into elite durum germplasm. Association mapping and efforts to transfer FHB resistance from the A, B, and D genome are underway to obtain improved levels of FHB resistance.

Genetic antibiotic resistance to orange wheat blossom midge was first reported in winter wheat [186]. The gene Sm1 was localized on chromosome 2BS [187]. Using a combination of molecular markers and bioassays, the $S m 1$ gene was transferred from hexaploid wheat to durum wheat. AAC Marchwell [167] was the first durum cultivar registered for commercial production in Canada with the $S m 1$ gene for antibiosis-based resistance to OWBM. Subsequently, several other durum wheat cultivars have been released with tolerance to midge (Table 1).

As of 2018, no other gene has been found to confer resistance to midge. Resistance to insect pests based on a single gene is often short-lived, due to the selection pressure for a virulent insect biotype. Consequently, to preserve the longevity of the $S m 1$ gene against midge mutating to virulence and overcoming the Sm1 gene [188,189], a stewardship plan has been implemented in Canada. Midge stewardship is based on using a varietal blend (VB) of $90 \%$ of a cultivar with the $\operatorname{Sm} 1$ gene, and $10 \%$ of a susceptible cultivar without the $S m 1$ gene as the refuge. Cultivars with the varietal blend 
are listed with a "VB" designation after the cultivar name (Table 1). For example, AAC Marchwell VB is a varietal blend of $90 \% \operatorname{Sm} 1$ carrier, AAC Marchwell, with 10\% non-Sm1 variety, AAC Raymore [164]. Subsequently, several other durum wheat cultivars have been released with $\operatorname{Sm} 1$ gene (Table 1).

The genetics of solid stem trait, which confers resistance to the wheat stem sawfly, has been studied in durum wheat [190]. A major gene for stem solidness, SSt1, has been localized on chromosome 3BL in a durum doubled haploid population of Kofa/W9262-260D3, and minor QTL on chromosomes 2A and $4 \mathrm{~A}$ that explained $0.2-0.3 \%$ of the phenotypic variance [191]. AAC Raymore and CDC Fortitude [165] were the first solid stem durum cultivars which confer resistance to the wheat stem sawfly (Table 1). Since then, several other solid stem durum cultivars have been released.

\subsection{Breeding for Quality Traits}

As noted previously, simultaneous selection for grain yield and protein concentration has been practiced since the mid-1990s in Canadian wheat breeding programs. Strongfield represents a paradigm shift in that it yielded $13.5 \%$ more grain than the check Kyle, and 0.3 units higher protein concentration. Furthermore, Strongfield had low Cd uptake, stronger gluten than Kyle, and more yellow pigment content than Kyle. Strongfield had shorter, stronger straws than Kyle. The excellent quality profile and agronomic package of Strongfield has served as a platform to incorporate other improvements, such as higher semolina yield in AAC Durafield [166] and AAC Congress [174], and higher yellow pigment in CDC Vivid [162] and AAC Spitfire [170]. The gluten strength boundaries are represented by Strongfield and AAC Cabri [169] at the lower end, with a gluten index in the lower 70s and Brigade at the upper end with a gluten index in the lower 90s. The alveograph P/L ratio indicates a desirable balance between extension and extensibility.

The brief historical review on cultivar development described above demonstrates that durum wheat breeding in Canada has made steady genetic improvement in yield and agronomic traits. Since 2010, there have been concomitant improvements in end-use quality traits, modest improvement in FHB resistance, introduction of new traits, such as resistance to wheat stem sawfly and orange wheat blossom midge, and tolerance to the herbicide imidazolinone (Table 1). Efforts have been made in recent years to develop durum wheat cultivars for niche markets based on some of the novel quality traits.

\section{Near-Term Agronomic Research Priorities}

For future perspectives in agronomic research for Canadian durum wheat, we suggest the following to be some of the priorities to address:

(i) Define the association of durum wheat productivity and arbuscular mycorrhizal (AM) fungi in the soil. The AM fungi are a normal component of the Canadian prairie ecosystems where they assist plants for nutrient uptake and, thus, increase crop productivity. Research is needed to define whether the colonization of AM in increasing durum wheat yield is dependent on genotype and soil fertility, or whether increasing grain yield of durum wheat can be accomplished through direct manipulation of soil microbiome, or whether there are significant interactions between year/site and preceding crops, and the structure of AM fungal community colonizing wheat roots. The factors affecting soil AM fungal resources in Canadian prairie need to be clearly identified before undertaking any further directions;

(ii) Assess whether breeding efforts can be taken to improve soil biological attributes through genotypes. Genetic variation exists in soil microbial community interactions among Canadian durum wheat genotypes and, more importantly, there is genetic variation in the influence of plant genotype on the soil microbial community on the performance of crop plants in rotation. However, it is unknown how this information may be used to build a strategy of selecting both the right preceding crop genotypes to engineer the beneficial soil microbial environments for subsequent durum wheat in a rotation. To our best knowledge, no direct selection for plant interaction with microbial community to improve durum wheat performance has been conducted 
on the Canadian prairie. To optimize the legendary effects of cropping systems rotation through managing soil microbial resources, we need multidisciplinary collaboration of durum breeders, agronomists, and soil biologists. The goals of this effort are to enhance the positive interaction between plant roots and soil microbial community, promote an effective feedback to the crop, and improve soil nutrient use efficiency through the improved genotypes;

(iii) Search for effective approaches to enhance NUE in durum wheat cultivation. Crop diversification in rotations on the semiarid Canadian prairie offers some significant benefits to the agroecosystems, including increased systems productivity and enhanced resource use efficiency. This practice has been shown to provide farmers with an alternative practice to conserve soil moisture, replace traditional summerfallow, and increase long-term sustainability. However, studies investigating the direct effect of diversified crop rotations on the NUE of durum wheat are little to none. We suggest multidisciplinary research, including breeding efforts, agronomic practices, and in soil biology, is needed to find solutions to enhance NUE in durum wheat production; and finally

(iv) Develop cultivar-specific cultivation systems for durum wheat production. There have been 23 cultivars released since 2010, introducing new traits such as solid stem, antibiosis to midge, imidazolinone tolerance, and a range of agronomic traits. There is a need to develop cultivar-specific management practices to optimize the productivity (yield, quality, biomass, and the impacts on soil and environment) for a cluster of cultivars with similar attributes. Positive outcomes can be achieved through a combination of mechanistic and systems-based modelling approaches using weather data, crop growth and development, soil and environmental conditions, and crop management practices.

\section{Conclusions}

Canadian durum wheat plays a significant role in world trade of durum grain. Durum wheat plays a crucial role for sustainable development of farming systems on the Canadian prairie that increases farmers' incomes and promotes the development of rural communities. During the recent 17 years, some significant improvement in genetic enhancement and agronomic management practices have been made in Canada, with the aim of increasing durum wheat productivity and reducing the potential negative impacts on the environment. However, Canadian durum wheat is facing some significant challenges. We suggest that attention should be paid to the following three agronomic research areas in the near term: first, oilseed crops and pulses have been intensively included in rotation systems, but recent evidence has shown that biotic stresses are threatening the systems' resilience and sustainability. Studies are needed to address how to sustain such a productive and profitable system for the long term. Second, high fertilizer $\mathrm{N}$ inputs are required for high grain yield and quality in durum wheat production, but higher inputs increase production costs, may degrade soil quality over time, and cause environmental concerns. Research is required to determine how to improve nutrient use efficiency and enhance crop productivity per unit of input, while minimizing detrimental effects on soil and environmental health. Finally, new durum wheat cultivars with higher symbiotic relationships, stronger capacity to combat abiotic and biotic stresses, in combination with superior agronomic traits, are required through breeding efforts. It is important to emphasize that we envision genetic enhancement programs that are closely integrated with multidiscipline foci described above, to meet the needs of Canadian durum production.

Author Contributions: Y.G. conceived the idea and designed the project; Y.N., L.L., R.M.D. and Y.G. conducted literature review, gathered data and performed statistical analysis; Y.R., R.M.D. and A.K.S. summarized genetic enhancement; All authors contribute to the draft manuscript; Y.G. finalized the paper; R.M.D., a native English speaker and an outstanding cereal breeder scientist ensured language satisfaction. 
Acknowledgments: The data from Durum Wheat Cooperative Tests were conducted under the auspices of the Prairie Recommending Committee for Wheat, Rye and Triticale and we acknowledge them for permission to use the data, and many people who conducted the field trials. We acknowledge Saskatchewan Crop Insurance Corporation for providing the multiple years of data of the registered durum wheat growers, and Barilla America Inc. for support on data interpretation and manuscript preparation through "Optimizing Durum Wheat Sustainability in North America" program.

Conflicts of Interest: The authors declare no conflict of interest.

\section{Abbreviations}

$\begin{array}{ll}\text { AM } & \text { arbuscular mycorrhizal fungi } \\ \text { DON } & \text { trichothecene deoxynivalenol } \\ \text { FHB } & \text { Fusarium head blight } \\ \text { GHG } & \text { greenhouse gas } \\ \text { OWBM } & \text { orange wheat blossom midge } \\ \text { NUE } & \text { nitrogen use efficiency } \\ \text { PHS } & \text { preharvest sprouting } \\ \text { VB } & \text { varietal blend } \\ \text { WUE } & \text { water use efficiency }\end{array}$

\section{References}

1. Tilman, D.; Balzer, C.; Hill, J.; Befort, B.L. Global food demand and the sustainable intensification of agriculture. Proc. Natl. Acad. Sci. USA 2011, 108, 20260-20264. [CrossRef] [PubMed]

2. Fedoroff, N.V.; Battisti, D.S.; Beachy, R.N.; Cooper, P.J.M.; Fischhoff, D.A.; Hodges, C.N.; Knauf, V.C.; Lobell, D.; Mazur, B.J.; Molden, D.; et al. Radically rethinking agriculture for the 21st century. Science 2010, 327, 833-834. [CrossRef] [PubMed]

3. Godfray, H.C.J.; Beddington, J.R.; Crute, I.R.; Haddad, L.; Lawrence, D.; Muir, J.F.; Pretty, J.; Robinson, S.; Thomas, S.M.; Toulmin, C.; et al. Food Security: The Challenge of Feeding 9 Billion People. Science 2010, 327, 812-818. [CrossRef]

4. FAOSTAT. FAO Statistical Yearbooks-World Food and Agriculture; Food and Agriculture Organization of the United Nations: Rome, Italy, 2014.

5. International-Grain-Council. 2018. Available online: https://www.igc.int/en/default.aspx (accessed on 25 April 2018).

6. Statistics-Canada. Durum Wheat Area as a Proportion of Total Field Crop Area by Census Division (CD), 2016; Statistics Canada: Ottawa, ON, Canada, 2018. Available online: http:/ /www.statcan.gc.ca/pub/95-634-x/ 2017001/article/54904/catm-ctra-045-eng.htm (accessed on 25 April 2018).

7. Statistics-Canada. Estimated Areas, Yield, Production, Average Farm Price and Total Farm Value of Principal Field Crops, in Metric and Imperial Units; Statistics Canada: Ottawa, ON, USA, 2018. Available online: http:/ / www5.statcan.gc.ca/cansim/a26?lang=eng\&id=10017 (accessed on 25 April 2018).

8. Statistics-Canada. Principal Field Crop Areas; Statistics Canada: Ottawa, ON, USA, 2017. Available online: https: / /www.statcan.gc.ca (accessed on 25 April 2018).

9. Gan, Y.T.; Miller, P.R.; McConkey, B.G.; Zentner, R.P.; Stevenson, F.C.; McDonald, C.L. Influence of diverse cropping sequences on durum wheat yield and protein in the semiarid northern Great Plains. Agron. J. 2003, 95, 245-252. [CrossRef]

10. Cutforth, H.W.; Jones, K.; Lang, T.-A. Agroclimate of the Brown Soil Zone of Southwestern Saskatchewan; Publication 379MOO88; Semi-Arid Prairie Agricultural Research Centre, Agriculture and Agri-Food Canada, Swift Current: Indian Head, SK, Canada, 1993.

11. Masud, M.B.; Khaliq, M.N.; Wheater, H.S. Projected changes to short- and long-duration precipitation extremes over the Canadian Prairie Provinces. Clim. Dyn. 2017, 49, 1597-1616. [CrossRef]

12. Asong, Z.E.; Khaliq, M.N.; Wheater, H.S. Multisite multivariate modeling of daily precipitation and temperature in the Canadian Prairie Provinces using generalized linear models. Clim. Dyn. 2016, 47, 2901-2921. [CrossRef] 
13. Mooleki, S.P.; Gan, Y.; Lemke, R.L.; Zentner, R.P.; Hamel, C. Effect of green manure crops, termination method, stubble crops, and fallow on soil water, available N, and exchangeable P. Can. J. Plant Sci. 2016, 96, 867-886. [CrossRef]

14. Zentner, R.P.; Campbell, C.A.; Biederbeck, V.O.; Selles, F.; Lemke, R.; Jefferson, P.G.; Gan, Y. Long-term assessment of management of an annual legume green manure crop for fallow replacement in the Brown soil zone. Can. J. Plant Sci. 2004, 84, 11-22. [CrossRef]

15. Schnitzer, M.; McArthur, D.F.E.; Schulten, H.R.; Kozak, L.M.; Huang, P.M. Long-term cultivation effects on the quantity and quality of organic matter in selected Canadian prairie soils. Geoderma 2006, 130, 141-156. [CrossRef]

16. Paré, M.C.; Lafond, J.; Pageau, D. Best management practices in Northern agriculture: A twelve-year rotation and soil tillage study in Saguenay-Lac-Saint-Jean. Soil Tillage Res. 2015, 150, 83-92. [CrossRef]

17. Schillinger, W.F.; Young, D.L. Best Management Practices for Summer Fallow in the World's Driest Rainfed Wheat Region. Soil Sci. Soc. Am. J. 2014, 78, 1707-1715. [CrossRef]

18. Zavattaro, L.; Costamagna, C.; Grignani, C.; Bechini, L.; Spiegel, A.; Lehtinen, T.; Guzmán, G.; Krüger, J.; D'Hose, T.; Pecio, A.; et al. Long-term effects of best management practices on crop yield and nitrogen surplus. Ital. J. Agron. 2015, 10, 47-50. [CrossRef]

19. Asgedom, H.; Kebreab, E. Beneficial management practices and mitigation of greenhouse gas emissions in the agriculture of the Canadian Prairie: A review. Agron. Sustain. Dev. 2011, 31, 433-451. [CrossRef]

20. Baird, J.; Jollineau, M.; Plummer, R.; Valenti, J. Exploring agricultural advice networks, beneficial management practices and water quality on the landscape: A geospatial social-ecological systems analysis. Land Use Policy 2016, 51, 236-243. [CrossRef]

21. Li, S.; Elliott, J.A.; Tiessen, K.H.D.; Yarotski, J.; Lobb, D.A.; Flaten, D.N. The effects of multiple beneficial management practices on hydrology and nutrient losses in a small watershed in the Canadian Prairies. J. Environ. Qual. 2011, 40, 1627-1642. [CrossRef] [PubMed]

22. Lychuk, T.E.; Moulin, A.P.; Izaurralde, R.C.; Lemke, R.L.; Johnson, E.N.; Olfert, O.O.; Brandt, S.A. Climate change, agricultural inputs, cropping diversity, and environmental covariates in multivariate analysis of future wheat, barley, and canola yields in Canadian Prairies: A case study. Can. J. Soil Sci. 2017, 97, 300-318. [CrossRef]

23. Cutforth, H.W.; McGinn, S.M.; McPhee, K.E.; Miller, P.R. Adaptation of Pulse Crops to the Changing Climate of the Northern Great Plains. Agron. J. 2007, 99, 1684-1699. [CrossRef]

24. McKenzie, R.H.; Bremer, E.; Middleton, A.B.; Pfiffner, P.G.; Woods, S.A. Optimum seeding date and rate for irrigated cereal and oilseed crops in southern Alberta. Can. J. Plant Sci. 2011, 91, 293-303. [CrossRef]

25. Hwang, S.F.; Gossen, B.D.; Turnbull, G.D.; Chang, K.F.; Howard, R.J.; Thomas, A.G. Effect of temperature, seeding date, fungicide seed treatment and inoculation with Fusarium avenaceum on seedling survival, root rot severity and yield of lentil. Can. J. Plant Sci. 2000, 80, 899-907. [CrossRef]

26. He, Y.; Wang, H.; Qian, B.; McConkey, B.; DePauw, R. How early can the seeding dates of spring wheat be under current and future climate in Saskatchewan, Canada? PLoS ONE 2012, 7. [CrossRef] [PubMed]

27. McCaig, T.N.; Gan, Y.T.; Clarke, P.; Clarke, J.M.; DePauw, R.M. Kernel colour changes associated with field weathering of spring wheat. Can. J. Plant Sci. 2006, 86, 371-377. [CrossRef]

28. Steel, R.; Torrie, J.; Dickey, D. Principles and procedures of statistics: A biometrical approach. J. Food Sci. 1997, 51, 574-576.

29. May, W.E.; Lafond, G.P.; Gan, Y.T.; Hucl, P.; Holzapfel, C.B.; Johnston, A.M.; Stevenson, C. Yield variability in Phalaris canariensis L. due to seeding date, seeding rate and nitrogen fertilizer. Can. J. Plant Sci. 2012, 92, 651-669. [CrossRef]

30. Gusta, L.V.; Johnson, E.N.; Nesbitt, N.T.; Kirkland, K.J. Effect of seeding date on canola seed quality and seed vigour. Can. J. Plant Sci. 2004, 84, 463-471. [CrossRef]

31. Johnson, E.N.; Miller, P.R.; Blackshaw, R.E.; Gan, Y.; Harker, K.N.; Clayton, G.W.; Kephart, K.D.; Wichman, D.M.; Topinka, K.; Kirkland, K.J. Seeding date and polymer seed coating effects on plant establishment and yield of fall-seeded canola in the Northern Great Plains. Can. J. Plant Sci. 2004, 84, 955-963. [CrossRef]

32. Gao, X.; Lukow, O.M.; Grant, C.A. Grain concentrations of protein, iron and zinc and bread making quality in spring wheat as affected by seeding date and nitrogen fertilizer management. J. Geochem. Explor. 2012, 121, 36-44. [CrossRef] 
33. Beres, B.L.; McKenzie, R.H.; Cárcamo, H.A.; Dosdall, L.M.; Evenden, M.L.; Yang, R.C.; Spaner, D.M. Influence of seeding rate, Nitrogen management, and micronutrient blend applications on pith expression in solid-stemmed spring wheat. Crop Sci. 2012, 52, 1316-1329. [CrossRef]

34. Isidro-Sánchez, J.; Perry, B.; Singh, A.K.; Wang, H.; DePauw, R.M.; Pozniak, C.J.; Beres, B.L.; Johnson, E.N.; Cuthbert, R.D. Effects of seeding rate on durum crop production and physiological responses. Agron. J. 2017, 109, 1981-1990. [CrossRef]

35. Clarke, J.M.; McLeod, J.G.; McCaig, T.N.; DePauw, R.M.; Knox, R.E.; Fernandez, M.R. AC Avonlea durum wheat. Can. J. Plant Sci. 1998, 78, 621-623. [CrossRef]

36. Beres, B.L.; Cárcamo, H.A.; Yang, R.C.; Spaner, D.M. Integrating spring wheat sowing density with variety selection to manage wheat stem sawfly. Agron. J. 2011, 103, 1755-1764. [CrossRef]

37. Nilsen, K.T.; Clarke, J.M.; Beres, B.L.; Pozniak, C.J. Sowing density and cultivar effects on pith expression in solid-stemmed durum wheat. Agron. J. 2016, 108, 219-228. [CrossRef]

38. Campbell, C.A.; Janzen, H.H.; Paustian, K.; Gregorich, E.G.; Sherrod, L.; Liang, B.C.; Zentner, R.P. Carbon storage in soils of the North American Great Plains: Effect of cropping frequency. Agron. J. 2005, 97, 349-363. [CrossRef]

39. Gan, Y.; Mooleki, S.P.; Lemke, R.L.; Zentner, R.P.; Ruan, Y. Durum wheat productivity in response to soil water and soil residual nitrogen associated with previous crop management. Agron. J. 2016, 108, 1468-1478. [CrossRef]

40. Campbell, C.A.; Zentner, R.P.; Basnyat, P.; DeJong, R.; Lemke, R.; Desjardins, R.; Reiter, M. Nitrogen mineralization under summer fallow and continuous wheat in the semiarid Canadian prairie. Can. J. Soil Sci. 2008, 88, 681-696. [CrossRef]

41. Myers, R.J.K.; Campbell, C.A.; Weier, K.L. Quantitative relationship between net nitrogen mineralization and moisture content of soils. Can. J. Soil Sci. 1982, 62, 111-124. [CrossRef]

42. McConkey, B.G.; Curtin, D.; Campbell, C.A.; Brandt, S.A.; Selles, F. Crop and soil nitrogen status of tilled and no-tillage systems in semiarid regions of Saskatchewan. Can. J. Soil Sci. 2002, 82, 489-498. [CrossRef]

43. Gan, Y.; Hamel, C.; Kutcher, H.R.; Poppy, L. Lentil enhances agroecosystem productivity with increased residual soil water and nitrogen. Renew. Agric. Food Syst. 2017, 32, 319-330. [CrossRef]

44. Lemke, R.L.; Vandenbygaart, A.J.; Campbell, C.A.; Lafond, G.P.; McConkey, B.G.; Grant, B. Long-term effects of crop rotations and fertilization on soil $\mathrm{C}$ and $\mathrm{N}$ in a thin Black Chernozem in southeastern Saskatchewan. Can. J. Soil Sci. 2012, 92, 449-461. [CrossRef]

45. Aulakh, M.S.; Rennie, D.A.; Paul, E.A. Gaseous nitrogen losses from cropped and summer-fallowed soils. Can. J. Soil Sci. 1982, 62, 187-196. [CrossRef]

46. Selles, F.; Clarke, J.M.; DePauw, R.M. Quantification of the yield and protein response to N and water availability by two wheat classes in the semiarid prairies. Can. J. Plant Sci. 2006, 86, 981-993. [CrossRef]

47. Clarke, J.M.; DePauw, R.M. Residue production of semidwarf and conventional wheat genotypes. Can. J. Plant Sci. 1993, 73, 769-776. [CrossRef]

48. Le Roy, D.G.; Smith, E.G.; MacCallum, P.J.; Janzen, H.H. Will summer fallow re-emerge in the dark brown soil zone of the Canadian prairie as a response to net return risk? Can. J. Plant Sci. 2017, 97, 214-249.

49. Dyer, J.A.; Desjardins, R.L. Analysis of trends in $\mathrm{CO}_{2}$ Emissions from Fossil Fuel use for farm fieldwork related to harvesting annual crops and hay, changing tillage practices and reduced summerfallow in Canada. J. Sustain. Agric. 2005, 25, 141-155. [CrossRef]

50. Liu, C.; Cutforth, H.; Chai, Q.; Gan, Y. Farming tactics to reduce the carbon footprint of crop cultivation in semiarid areas. A review. Agron. Sustain. Dev. 2016, 36, 69. [CrossRef]

51. Shrestha, B.M.; McConkey, B.G.; Smith, W.N.; Desjardins, R.L.; Campbell, C.A.; Grant, B.B.; Miller, P.R. Effects of crop rotation, crop type and tillage on soil organic carbon in a semiarid climate. Can. J. Soil Sci. 2013, 93, 137-146. [CrossRef]

52. Dyer, J.A.; Desjardins, R.L. A review and evaluation of fossil energy and carbon dioxide emissions in Canadian agriculture. J. Sustain. Agric. 2009, 33, 210-228. [CrossRef]

53. Janzen, H.H.; Angers, D.A.; Boehm, M.; Bolinder, M.; Desjardins, R.L.; Dyer, J.A.; Ellert, B.H.; Gibb, D.J.; Gregorich, E.G.; Helgason, B.L.; et al. A proposed approach to estimate and reduce net greenhouse gas emissions from whole farms. Can. J. Soil Sci. 2006, 86, 401-418. [CrossRef] 
54. Gan, Y.; Liang, C.; Campbell, C.A.; Zentner, R.P.; Lemke, R.L.; Wang, H.; Yang, C. Carbon footprint of spring wheat in response to fallow frequency and soil carbon changes over 25 years on the semiarid Canadian prairie. Eur. J. Agron. 2012, 43, 175-184. [CrossRef]

55. Curtin, D.; Wang, H.; Selles, F.; Zentner, R.P.; Biederbeck, V.O.; Campbell, C.A. Legume green manure as partial fallow replacement in semiarid Saskatchewan: Effect on carbon fluxes. Can. J. Soil Sci. 2000, 80, 499-505. [CrossRef]

56. Kirkegaard, J.A.; Ryan, M.H. Magnitude and mechanisms of persistent crop sequence effects on wheat. Field Crops Res. 2014, 164, 154-165. [CrossRef]

57. Gan, Y.; Hamel, C.; O’Donovan, J.T.; Cutforth, H.; Zentner, R.P.; Campbell, C.A.; Niu, Y.; Poppy, L. Diversifying crop rotations with pulses enhances system productivity. Sci. Rep. 2015, 5, 14625. [CrossRef] [PubMed]

58. Harker, K.N.; O’Donovan, J.T.; Turkington, T.K.; Blackshaw, R.E.; Lupwayi, N.Z.; Smith, E.G.; Klein-Gebbinck, H.; Dosdall, L.M.; Hall, L.M.; Willenborg, C.J.; et al. High-yield no-till canola production on the Canadian prairies. Can. J. Plant Sci. 2012, 92, 221-233. [CrossRef]

59. Campbell, C.A.; Zentner, R.P.; Gameda, S.; Blomert, B.; Wall, D.D. Production of annual crops on the Canadian prairies: Trends during 1976-1998. Can. J. Soil Sci. 2002, 82, 45-57. [CrossRef]

60. Miller, P.; Gan, Y.; McConkey, B.; McDonald, C. Pulse crops for the northern Great Plains. II: Cropping sequence effects on cereal, oilseed, and pulse crops. Agron. J. 2003, 95, 980-986. [CrossRef]

61. Miller, P.R.; Gan, Y.; McConkey, B.G.; McDonald, C.L. Pulse crops in the Northern Great Plains. I. Grain productivity and residual effects on soil water and nitrogen. Agron. J. 2003, 95, 972-979. [CrossRef]

62. Hossain, Z.; Wang, X.; Hamel, C.; Diane Knight, J.; Morrison, M.J.; Gan, Y. Biological nitrogen fixation by pulse crops on semiarid Canadian prairies. Can. J. Plant Sci. 2016, 97, 119-131.

63. Hossain, Z.; Wang, X.; Hamel, C.; Gan, Y. Nodulation and nitrogen accumulation in pulses grown on the Canadian Prairie. Can. J. Plant Sci. 2018, 98, 527-545. [CrossRef]

64. Hunt, J.R.; Browne, C.; McBeath, T.M.; Verburg, K.; Craig, S.; Whitbread, A.M. Summer fallow weed control and residue management impacts on winter crop yield though soil water and $\mathrm{N}$ accumulation in a winter-dominant, low rainfall region of southern Australia. Crop Pasture Sci. 2013, 64, 922-934. [CrossRef]

65. De Jong, R.; Campbell, C.A.; Zentner, R.P.; Basnyat, P.; Cutforth, H.; Desjardins, R. Quantifying soil water conservation in the semiarid region of Saskatchewan, Canada: Effect of fallow frequency and $\mathrm{N}$ fertilizer. Can. J. Soil Sci. 2008, 88, 461-475. [CrossRef]

66. Liu, L.; Gan, Y.; Bueckert, R.; Van Rees, K. Rooting systems of oilseed and pulse crops. II: Vertical distribution patterns across the soil profile. Field Crops Res. 2011, 122, 248-255. [CrossRef]

67. Liu, L.; Gan, Y.; Bueckert, R.; Van Rees, K. Rooting systems of oilseed and pulse crops I: Temporal growth patterns across the plant developmental periods. Field Crops Res. 2011, 122, 256-263. [CrossRef]

68. Wang, X.; Gan, Y.; Hamel, C.; Lemke, R.; McDonald, C. Water use profiles across the rooting zones of various pulse crops. Field Crops Res. 2012, 134, 130-137. [CrossRef]

69. Niu, Y.; Bainard, L.; Bandara, M.S.; Hamel, C.; Gan, Y. Soil residual water and nutrients explain about 30\% of the rotational effect in 4-year pulse-intensified rotation systems. Can. J. Plant Sci. 2017, 97, 852-864. [CrossRef]

70. Campbell, C.A.; McConkey, B.G.; Zentner, R.P.; Selles, F.; Dyck, F.B. Benefits of wheat stubble strips for conserving snow in southwestern Saskatchewan. J. Soil Water Conserv. 1992, 47, 112-115.

71. Steppuhn, H. Snow cover retention capacities for direct combined wheat and barley stubble in windy environments. Can. J. Agric. Eng. 1994, 36, 215-223.

72. Cutforth, H.W.; Jefferson, P.G.; Campbell, C.A. Lower limit of available water for three plant species grown on a medium-textured soil in southwestern Saskatchewan. Can. J. Soil Sci. 1991, 71, 247-252. [CrossRef]

73. He, Y.; Wang, H.; Qian, B.; McConkey, B.; Cutforth, H.; Lemke, R.; DePauw, R.M.; Brandt, K.; Hu, K.L.; Hoogenboom, G. Effects of climate change on killing frost in the Canadian prairies. Clim. Res. 2012, 54, 221-231. [CrossRef]

74. DePauw, R.M.; Knox, R.E.; Humphreys, D.G.; Thomas, J.B.; Fox, S.L.; Brown, P.D.; Singh, A.K.; Pozniak, C.; Randhawa, H.S.; Fowler, D.B.; et al. New breeding tools impact Canadian commercial farmer fields. Czech J. Genet. Plant Breed. 2011, 47, 28-34. [CrossRef] 
75. Gan, Y.T.; Campbell, C.A.; Janzen, H.H.; Lemke, R.; Liu, L.P.; Basnyat, P.; McDonald, C.L. Root mass for oilseed and pulse crops: Growth and distribution in the soil profile. Can. J. Plant Sci. 2009, 89, 883-893. [CrossRef]

76. Campbell, C.A.; Selles, F.; Zentner, R.P.; De Jong, R.; Lemke, R.; Hamel, C. Nitrate leaching in the semiarid prairie: Effect of cropping frequency, crop type, and fertilizer after 37 years. Can. J. Soil Sci. 2006, 86, 701-710. [CrossRef]

77. Kröbel, R.; Campbell, C.A.; Zentner, R.P.; Lemke, R.; Steppuhn, H.; Desjardins, R.L.; De Jong, R. Nitrogen and phosphorus effects on water use efficiency of spring wheat grown in a semi-arid region of the Canadian prairies. Can. J. Soil Sci. 2012, 92, 573-587. [CrossRef]

78. St. Luce, M.; Grant, C.A.; Ziadi, N.; Zebarth, B.J.; O’Donovan, J.T.; Blackshaw, R.E.; Harker, K.N.; Johnson, E.N.; Gan, Y.; Lafond, G.P.; et al. Preceding crops and nitrogen fertilization influence soil nitrogen cycling in no-till canola and wheat cropping systems. Field Crops Res. 2016, 191, 20-32. [CrossRef]

79. Borrell, A.N.; Shi, Y.; Gan, Y.; Bainard, L.D.; Germida, J.J.; Hamel, C. Fungal diversity associated with pulses and its influence on the subsequent wheat crop in the Canadian prairies. Plant Soil 2017, 414, 13-31. [CrossRef]

80. Yang, C.; Hamel, C.; Gan, Y.; Vujanovic, V. Bacterial endophytes mediate positive feedback effects of early legume termination times on the yield of subsequent durum wheat crops. Can. J. Microbiol. 2012, 58, 1368-1377. [CrossRef] [PubMed]

81. Yang, C.; Hamel, C.; Gan, Y.; Vujanovic, V. Pyrosequencing reveals how pulses influence rhizobacterial communities with feedback on wheat growth in the semiarid Prairie. Plant Soil 2013, 367, 493-505. [CrossRef]

82. Bainard, L.D.; Navarro-Borrell, A.; Hamel, C.; Braun, K.; Hanson, K.; Gan, Y. Increasing the frequency of pulses in crop rotations reduces soil fungal diversity and increases the proportion of fungal pathotrophs in a semiarid agroecosystem. Agric. Ecosyst. Environ. 2017, 240, 206-214. [CrossRef]

83. Hamel, C.; Gan, Y.; Sokolski, S.; Bainard, L.D. High frequency cropping of pulses modifies soil nitrogen level and the rhizosphere bacterial microbiome in 4-year rotation systems of the semiarid prairie. Appl. Soil Ecol. 2018, 126, 47-56. [CrossRef]

84. Khakbazan, M.; Grant, C.A.; Huang, J.; Berry, N.J.; Smith, E.G.; O’Donovan, J.T.; Blackshaw, R.E.; Harker, K.N.; Lafond, G.P.; Johnson, E.N.; et al. Preceding crops and nitrogen effects on crop energy use efficiency in canola and barley. Agron. J. 2016, 108, 1079-1088. [CrossRef]

85. St. Luce, M.; Grant, C.A.; Zebarth, B.J.; Ziadi, N.; O’Donovan, J.T.; Blackshaw, R.E.; Harker, K.N.; Johnson, E.N.; Gan, Y.; Lafond, G.P.; et al. Legumes can reduce economic optimum nitrogen rates and increase yields in a wheat-canola cropping sequence in western Canada. Field Crops Res. 2015, 179, 12-25. [CrossRef]

86. Gan, Y.; Liang, C.; Wang, X.; McConkey, B.G. Lowering carbon footprint of durum wheat by diversifying cropping systems. Field Crops Res. 2011, 122, 199-206. [CrossRef]

87. Bazghaleh, N.; Hamel, C.; Gan, Y.; Knight, J.D.; Vujanovic, V.; Cruz, A.F.; Ishii, T. Phytochemicals induced in chickpea roots selectively and non-selectively stimulate and suppress fungal endophytes and pathogens. Plant Soil 2016, 409, 479-493. [CrossRef]

88. Ellouze, W.; Hamel, C.; Cruz, A.F.; Ishii, T.; Gan, Y.; Bouzid, S.; St-Arnaud, M. Phytochemicals and spore germination: At the root of AMF host preference? Appl. Soil Ecol. 2012, 60, 98-104. [CrossRef]

89. Niu, Y.; Bainard, L.D.; May, W.E.; Hossain, Z.; Hamel, C.; Gan, Y. Intensified pulse rotations buildup pea rhizosphere pathogens in cereal and pulse based cropping systems. Front. Microbiol. 2018, 9, 1909. [CrossRef] [PubMed]

90. Gao, X.; Grant, C.A. Cadmium and zinc concentration in grain of durum wheat in relation to phosphorus fertilization, crop sequence and tillage management. Appl. Environ. Soil Sci. 2012, 2012, 817107. [CrossRef]

91. Gulden, R.H.; Tenuta, M.; Mitchell, S.; Langarica Fuentes, A.; Daniell, T.J. Preceding crop and weed management history affect denitrification and denitrifier community structure throughout the development of durum wheat. Agric. Ecosyst. Environ. 2015, 212, 49-63. [CrossRef]

92. Kubota, H.; Iqbal, M.; Dyck, M.; Quideau, S.; Yang, R.C.; Spaner, D. Investigating genetic progress and variation for nitrogen use efficiency in spring wheat. Crop Sci. 2018, 58, 1542-1557. [CrossRef]

93. Mansour, E.; Merwad, A.M.A.; Yasin, M.A.T.; Abdul-Hamid, M.I.E.; El-Sobky, E.E.A.; Oraby, H.F. Nitrogen use efficiency in spring wheat: Genotypic variation and grain yield response under sandy soil conditions. J. Agric. Sci. 2017, 155, 1407-1423. [CrossRef] 
94. Han, M.; Okamoto, M.; Beatty, P.H.; Rothstein, S.J.; Good, A.G. The genetics of nitrogen use efficiency in crop plants. Annu. Rev. Genet. 2015, 49, 269-289. [CrossRef] [PubMed]

95. Chaplot, P.C. Effect of balanced fertilization, organic manures and bioregulator on nutrient uptake by late sown wheat and soil nutrient status. Ann. Biol. 2014, 30, 627-630.

96. Kröbel, R.; Campbell, C.A.; Zentner, R.P.; Lemke, R.; Desjardins, R.L.; Karimi-Zindashty, Y. Effect of N, P and cropping frequency on nitrogen use efficiencies of spring wheat in the Canadian semi-arid prairie. Can. J. Plant Sci. 2012, 92, 141-154. [CrossRef]

97. Grant, C.A.; O’Donovan, J.T.; Blackshaw, R.E.; Harker, K.N.; Johnson, E.N.; Gan, Y.; Lafond, G.P.; May, W.E.; Turkington, T.K.; Lupwayi, N.Z.; et al. Residual effects of preceding crops and nitrogen fertilizer on yield and crop and soil $\mathrm{N}$ dynamics of spring wheat and canola in varying environments on the Canadian prairies. Field Crops Res. 2016, 192, 86-102. [CrossRef]

98. Malhi, S.S.; Oliver, E.; Mayerle, G.; Kruger, G.; Gill, K.S. Improving effectiveness of seedrow-placed urea with urease inhibitor and polymer coating for durum wheat and canola. Commun. Soil Sci. Plant Anal. 2003, 34, 1709-1727. [CrossRef]

99. Bremner, J.M. Recent research on problems in the use of urea as a nitrogen fertilizer. Fertil. Res. 1995, 42, 321-329. [CrossRef]

100. Christianson, C.B.; Baethgen, W.E.; Carmona, G.; Howard, R.G. Microsite reactions of urea-nBTPT fertilizer on the soil surface. Soil Biol. Biochem. 1993, 25, 1107-1117. [CrossRef]

101. Selles, F.; Clarke, J.M.; Zentner, R.P.; Campbell, C.A. Effects of source and placement of phosphorus on concentration of cadmium in the grain of two durum wheat cultivars. Can. J. Plant Sci. 2003, 83, 475-482. [CrossRef]

102. Beres, B.L.; Bremer, E.; Sadasivaiah, R.S.; Clarke, J.M.; Graf, R.J.; McKenzie, R.H.; Dyck, R.J. Post-emergence application of $\mathrm{N}$ fertilizer to improve grain yield and quality of irrigated durum and bread wheat. Can. J. Plant Sci. 2008, 88, 509-512. [CrossRef]

103. May, W.E.; Fernandez, M.R.; Selles, F.; Lafond, G.P. Agronomic practices to reduce leaf spotting and Fusarium kernel infections in durum wheat on the Canadian prairies. Can. J. Plant Sci. 2014, 94, 141-152. [CrossRef]

104. McNeal, F.H.; Berg, M.A.; Brown, P.L.; McGuire, C.F. Productivity and Quality Response of Five Spring Wheat Genotypes, Triticum aestivum, L., to Nitrogen Fertilizer1. Agron. J. 1971, 63, 908-910. [CrossRef]

105. Knapp, J.S.; Harms, C.L. Nitrogen Fertilization and Plant Growth Regulator Effects on Yield and Quality of Four Wheat Cultivars. J. Prod. Agric. 1988, 1, 94-98. [CrossRef]

106. Selles, F.; Campbell, C.A.; Zentner, R.P.; Curtin, D.; James, D.C.; Basnyat, P. Phosphorus use efficiency and long-term trends in soil available phosphorus in wheat production systems with and without nitrogen fertilizer. Can. J. Soil Sci. 2011, 91, 39-52. [CrossRef]

107. Campbell, C.A.; Zentner, R.P.; Selles, F.; Jefferson, P.G.; McConkey, B.G.; Lemke, R.; Blomert, B.J. Long-term effect of cropping system and nitrogen and phosphorus fertilizer on production and nitrogen economy of grain crops in a Brown Chernozem. Can. J. Plant Sci. 2005, 85, 81-93. [CrossRef]

108. Karamanos, R.E.; Harapiak, J.T.; Flore, N.A. Application of seed-row potash to barley (Hordeum vulgare L.) grown on soils with high "available" potassium levels. Can. J. Plant Sci. 2003, 83, 291-303. [CrossRef]

109. May, W.E.; Fernandez, M.R.; Holzapfel, C.B.; Lafond, G.P. Influence of phosphorus, nitrogen, and potassium chloride placement and rate on durum wheat yield and quality. Agron. J. 2008, 100, 1173-1179. [CrossRef]

110. Bailey, L.; Grant, C.; Flore, N.; Harapiak, J. Effect of phosphate source, rate and cadmium content and use of Penicillium bilaii on phosphorus, zinc and cadmium concentration in durum wheat grain. J. Sci. Food Agric. 2002, 82, 301-308.

111. Jiao, Y.; Grant, C.A.; Bailey, L.D. Growth and nutrient response of flax and durum wheat to phosphorus and zinc fertilizers. Can. J. Plant Sci. 2007, 87, 461-470. [CrossRef]

112. Campbell, C.A.; Selles, F.; Lafond, G.P.; Biederbeck, V.O.; Zentner, R.P. Tillage-Fertilizer changes: Effect on some soil quality attributes under long-term crop rotations in a thin Black Chernozem. Can. J. Soil Sci. 2001, 81, 157-165. [CrossRef]

113. Campbell, C.A.; Selles, F.; Lafond, G.P.; Zentner, R.P. Adopting zero tillage management: Impact on soil $\mathrm{C}$ and $\mathrm{N}$ under long-term crop rotations in a thin Black Chernozem. Can. J. Soil Sci. 2001, 81, 139-148. [CrossRef]

114. Chai, Q.; Qin, A.Z.; Gan, Y.T.; Yu, A.Z. Higher yield and lower carbon emission by intercropping maize with rape, pea, and wheat in arid irrigation areas. Agron. Sustain. Dev. 2014, 34, 535-543. [CrossRef] 
115. Statistics-Canada. Fertilizer and Pesticide Management in Canada, Catalogue No. 21-021-MIE No. 003; Statistics Canada: Ottawa, ON, Canada, 2004.

116. Tremblay, N.; Wang, Z.; Cerovic, Z.G. Sensing crop nitrogen status with fluorescence indicators. A review. Agron. Sustain. Dev. 2012, 32, 451-464. [CrossRef]

117. Bronson, K.F.; White, J.W.; Conley, M.M.; Hunsaker, D.J.; Thorp, K.R.; French, A.N.; Mackey, B.E.; Holland, K.H. Active optical sensors in irrigated durum wheat: Nitrogen and water effects. Agron. J. 2017, 109, 1060-1071. [CrossRef]

118. Raghuvanshi, R.; Chaudhari, A.; Kumar, G.N. Amelioration of cadmium- and mercury-induced liver and kidney damage in rats by genetically engineered probiotic Escherichia coli Nissle 1917 producing pyrroloquinoline quinone with oral supplementation of citric acid. Nutrition 2016, 32, 1285-1294. [CrossRef] [PubMed]

119. Büyükkiliç Yanardağ, A.; Mermut, A.R.; Cano, Á.F.; Garces, D.M.C.; Yanardă̆, İ.H. Cadmium contents of soils and durum and bread wheats on Harran Plain, southeast Turkey. Turk. J. Agric. For. 2016, 40, 772-782. [CrossRef]

120. Harris, N.S.; Taylor, G.J. Cadmium uptake and partitioning in durum wheat during grain filling. BMC Plant Biol. 2013, 13, 103. [CrossRef] [PubMed]

121. Quinn, C.J.; Mohammad, A.; Macfie, S.M. Accumulation of cadmium in near-isogenic lines of durum wheat (Triticum turgidum L. var durum): The role of transpiration. Physiol. Mol. Biol. Plants 2011, 17, 317-325. [CrossRef] [PubMed]

122. Jiao, Y.; Grant, C.A.; Bailey, L.D. Effects of phosphorus and zinc fertilizer on cadmium uptake and distribution in flax and durum wheat. J. Sci. Food Agric. 2004, 84, 777-785. [CrossRef]

123. Gao, X.; Flaten, D.N.; Tenuta, M.; Grimmett, M.G.; Gawalko, E.J.; Grant, C.A. Soil solution dynamics and plant uptake of cadmium and zinc by durum wheat following phosphate fertilization. Plant Soil 2011, 338, 423-434. [CrossRef]

124. Gao, X.; Brown, K.R.; Racz, G.J.; Grant, C.A. Concentration of cadmium in durum wheat as affected by time, source and placement of nitrogen fertilization under reduced and conventional-tillage management. Plant Soil 2010, 337, 341-354. [CrossRef]

125. Knox, R.E.; Pozniak, C.J.; Clarke, F.R.; Clarke, J.M.; Houshmand, S.; Singh, A.K. Chromosomal location of the cadmium uptake gene (Cdu1) in durum wheat. Genome 2009, 52, 741-747. [CrossRef] [PubMed]

126. Garrett, R.G.; MacLaurin, A.I.; Gawalko, E.J.; Tkachuk, R.; Hall, G.E.M. A prediction model for estimating the cadmium content of durum wheat from soil chemistry. J. Geochem. Explor. 1998, 64, 101-110. [CrossRef]

127. Esmaeili Taheri, A.; Hamel, C.; Gan, Y. Cropping practices impact fungal endophytes and pathogens in durum wheat roots. Appl. Soil Ecol. 2016, 100, 104-111. [CrossRef]

128. Ellouze, W.; Hamel, C.; Vujanovic, V.; Gan, Y.; Bouzid, S.; St-Arnaud, M. Chickpea genotypes shape the soil microbiome and affect the establishment of the subsequent durum wheat crop in the semiarid North American Great Plains. Soil Biol. Biochem. 2013, 63, 129-141. [CrossRef]

129. Ellouze, W.; Hamel, C.; Singh, A.K.; Mishra, V.; DePauw, R.; Knox, R. Abundance of the arbuscular mycorrhizal fungal taxa associated with the roots and rhizosphere soil of different durum wheat cultivars in the Canadian prairies. Can. J. Microbiol. 2018, 64, 527-536. [CrossRef] [PubMed]

130. Bazghaleh, N.; Hamel, C.; Gan, Y.; Tar'an, B.; Knight, J.D. Genotype-specific variation in the structure of root fungal communities is related to chickpea plant productivity. Appl. Environ. Microbiol. 2015, 81, 2368-2377. [CrossRef] [PubMed]

131. Yang, C.; Hamel, C.; Gan, Y.; Vujanovic, V. Tag-encoded pyrosequencing analysis of the effects of fungicide application and plant genotype on rhizobacterial communities. Appl. Soil Ecol. 2012, 60, 92-97. [CrossRef]

132. Lupwayi, N.Z.; Harker, K.N.; O’Donovan, J.T.; Turkington, T.K.; Blackshaw, R.E.; Hall, L.M.; Willenborg, C.J.; Gan, Y.; Lafond, G.P.; May, W.E.; et al. Relating soil microbial properties to yields of no-till canola on the Canadian prairies. Eur. J. Agron. 2015, 62, 110-119. [CrossRef]

133. Cruz, A.F.; Hamel, C.; Yang, C.; Matsubara, T.; Gan, Y.; Singh, A.K.; Kuwada, K.; Ishii, T. Phytochemicals to suppress Fusarium head blight in wheat-chickpea rotation. Phytochemistry 2012, 78, 72-80. [CrossRef] [PubMed]

134. Ellouze, W.; Hamel, C.; DePauw, R.M.; Knox, R.E.; Cuthbert, R.D.; Singh, A.K. Potential to breed for mycorrhizal association in durum wheat. Can. J. Microbiol. 2015, 62, 263-271. [CrossRef] [PubMed] 
135. Ellouze, W.; Esmaeili Taheri, A.; Bainard, L.D.; Yang, C.; Bazghaleh, N.; Navarro-Borrell, A.; Hanson, K.; Hamel, C. Soil Fungal Resources in Annual Cropping Systems and Their Potential for Management. BioMed Res. Int. 2014, 2014, 531824. [CrossRef] [PubMed]

136. Rodriguez, A.; Sanders, I.R. The role of community and population ecology in applying mycorrhizal fungi for improved food security. ISME J. 2015, 9, 1053-1061. [CrossRef] [PubMed]

137. Esmaeili Taheri, A.; Hamel, C.; Gan, Y. Pyrosequencing reveals the impact of foliar fungicide application to chickpea on root fungal communities of durum wheat in subsequent year. Fungal Ecol. 2015, 15, 73-81. [CrossRef]

138. Yang, C.; Hamel, C.; Gan, Y. Incongruous variation of denitrifying bacterial communities as soil $\mathrm{N}$ level rises in Canadian canola fields. Appl. Soil Ecol. 2015, 89, 93-101. [CrossRef]

139. Banniza, S.; Armstrong-Cho, C.L.; Gan, Y.; Chongo, G. Evaluation of fungicide efficacy and application frequency for the control of ascochyta blight in chickpea. Can. J. Plant Pathol. 2011, 33, 135-149. [CrossRef]

140. Yang, C.; Hamel, C.; Vujanovic, V.; Gan, Y. Nontarget effects of foliar fungicide application on the rhizosphere: Diversity of nifH gene and nodulation in chickpea field. J. Appl. Microbiol. 2012, 112, 966-974. [CrossRef] [PubMed]

141. Bailey, K.L.; Gossen, B.D.; Gugel, R.K.; Morrall, R.A.A. Diseases of Field Crops in Canada, 3rd ed.; Canadian Phytopathological Society, University Extension Press, University of Saskatchewan: Saskatoon, SK, Canada, 2003.

142. DePauw, R.M.; Malhi, S.S.; Bullock, P.R.; Gan, Y.T.; McKenzie, R.H.; Larney, F.J.; Janzen, H.H.; Cutforth, H.W.; Wang, H. Wheat Production in North High Latitudes-Canadian Example; Angus, W., Bonjean, A., van Ginkel, M., Eds.; World Wheat Book 2; A History of Wheat Breeding; Lavoisier Tech et Doc: Paris, France, 2011; Volume 2, pp. 607-651.

143. Langevin, F.; Eudes, F.; Comeau, A. Effect of trichothecenes produced by Fusarium graminearum during Fusarium head blight development in six cereal species. Eur. J. Plant Pathol. 2004, 110, 735-746. [CrossRef]

144. Fernandez, M.R.; Clarke, F.R.; Knox, R.E.; Clarke, J.M.; Singh, A.K. Quantification of effects of leaf spotting diseases on grain yield and market quality of durum wheat using near-isogenic lines. Can. J. Plant Pathol. 2010, 32, 177-187. [CrossRef]

145. Fernandez, M.R.; May, W.E.; Chalmers, S.; Savard, M.E.; Singh, A.K. Are early foliar fungicide applications on durum wheat grown in southeast Saskatchewan beneficial in increasing grain productivity? Can. J. Plant Sci. 2014, 94, 891-903. [CrossRef]

146. Fernandez, M.R.; Stevenson, C.F.; Hodge, K.; Dokken-Bouchard, F.; Pearse, P.G.; Waelchli, F.; Brown, A.; Peluola, C. Assessing effects of climatic change, region and agronomic practices on leaf spotting of bread and durum wheat in the western Canadian Prairies, from 2001 to 2012. Agron. J. 2016, 108, 1180-1195. [CrossRef]

147. Fernandez, M.R.; Clarke, J.M.; DePauw, R.M. The effect of plant height on tan spot on durum wheat in southern Saskatchewan. Crop Sci. 2002, 42, 159-164. [CrossRef] [PubMed]

148. Wang, H.; Fernandez, M.R.; Clarke, F.R.; DePauw, R.M.; Clarke, J.M. Effect of leaf spotting diseases on grain yield and seed traits of wheat in southern Saskatchewan. Can. J. Plant Sci. 2002, 82, 507-512. [CrossRef]

149. Wang, H.; Fernandez, M.R.; Clarke, F.R.; DePauw, R.M.; Clarke, J.M. Effects of foliar fungicides on kernel black point of wheat in southern Saskatchewan. Can. J. Plant Pathol. 2002, 24, 287-293. [CrossRef]

150. Beres, B.L.; Dosdall, L.M.; Weaver, D.K.; Cárcamo, H.A.; Spaner, D.M. Biology and integrated management of wheat stem sawfly and the need for continuing research. Can. Entomol. 2011, 143, 105-125. [CrossRef]

151. Lamb, R.J.; Wise, I.L.; Olfert, O.O.; Gavloski, J.; Barker, P.S. Distribution and seasonal abundance of Sitodiplosis mosellana (Diptera: Cecidomyiidae) in spring wheat. Can. Entomol. 1999, 131, 387-397. [CrossRef]

152. Smith, M.A.H.; Lamb, R.J. Factors influencing oviposition by Sitodiplosis mosellana (Diptera: Cecidomyiidae) on wheat spikes (Gramineae). Can. Entomol. 2001, 133, 533-548. [CrossRef]

153. Bokore, F.E.; Knox, R.E.; Cuthbert, R.D.; Ruan, Y.; DePauw, R.M. Effects of media supplements on doubled haploid production in durum wheat. Can. J. Plant Sci. 2016, 97, 65-71. [CrossRef]

154. Clarke, J.M.; Clarke, F.R.; Pozniak, C.J. Forty-six years of genetic improvement in Canadian durum wheat cultivars. Can. J. Plant Sci. 2010, 90, 791-801. [CrossRef]

155. McCaig, T.N.; Clarke, J.M. Breeding durum wheat in western Ganada: Historical trends in yield and related variables. Can. J. Plant Sci. 1995, 75, 55-60. [CrossRef]

156. Singh, A.K.; Clarke, J.M.; Knox, R.E.; DePauw, R.M.; McCaig, T.N.; Fernandez, M.R.; Clarke, F.R. Transcend Durum wheat. Can. J. Plant Sci. 2012, 92, 809-813. [CrossRef] 
157. DePauw, R.M.; Knox, R.E.; Clarke, F.R.; Wang, H.; Fernandez, M.R.; Clarke, J.M.; McCaig, T.N. Shifting undesirable correlations. Euphytica 2007, 157, 409-415. [CrossRef]

158. McCallum, B.D.; DePauw, R.M. A review of wheat cultivars grown in the Canadian prairies. Can. J. Plant Sci. 2008, 88, 649-677. [CrossRef]

159. Townley-Smith, T.F.; Patterson, L.A.; DePauw, R.M.; Lendrum, C.W.B.; McCrystal, G.E. Kyle Durum Wheat. Can. J. Plant Sci. 1987, 67, 225-227. [CrossRef]

160. Clarke, J.M.; Knox, R.E.; DePauw, R.M.; Clarke, F.R.; Fernandez, M.R.; McCaig, T.N.; Singh, A.K. Brigade durum wheat. Can. J. Plant Sci. 2009, 89, 505-509. [CrossRef]

161. Pozniak, C.J. CDC Desire durum wheat. Can. J. Plant Sci. 2013, 93, 1265-1270. [CrossRef]

162. Pozniak, C.J. CDC Vivid durum wheat. Can. J. Plant Sci. 2013, 93, 137-141. [CrossRef]

163. Singh, A.K.; Clarke, J.M.; DePauw, R.M.; Knox, R.E.; McCaig, T.N.; Cuthbert, R.D. AAC current durum wheat. Can. J. Plant Sci. 2015, 95, 589-594. [CrossRef]

164. Singh, A.K.; Clarke, J.M.; Knox, R.E.; DePauw, R.M.; McCaig, T.N.; Cuthbert, R.D.; Clarke, F.R.; Fernandez, M.R. AAC Raymore durum wheat. Can. J. Plant Sci. 2014, 94, 1289-1296. [CrossRef]

165. Pozniak, C.J.; Nilsen, K.; Clarke, J.M.; Beres, B.L. CDC Fortitude durum wheat. Can. J. Plant Sci. 2015, 95, 1013-1019. [CrossRef]

166. Singh, A.K.; DePauw, R.M.; Knox, R.E.; Clarke, J.M.; McCaig, T.N.; Cuthbert, R.D.; Ruan, Y. AAC Durafield durum wheat. Can. J. Plant Sci. 2016, 96, 719-725. [CrossRef]

167. Singh, A.K.; Clarke, J.M.; Knox, R.E.; DePauw, R.M.; Wise, I.; Thomas, J.; McCaig, T.N.; Cuthbert, R.D.; Clarke, F.R.; Fernandez, M.R.; et al. AAC Marchwell durum wheat. Can. J. Plant Sci. 2015, 95, 189-195. [CrossRef]

168. Pozniak, C.J.; Clarke, J.M. CDC carbide durum wheat. Can. J. Plant Sci. 2015, 95, 1007-1012. [CrossRef]

169. Singh, A.K.; DePauw, R.M.; Knox, R.E.; Clarke, J.M.; McCaig, T.N.; Cuthbert, R.D.; Ruan, Y. AAC Cabri durum wheat. Can. J. Plant Sci. 2016, 97, 135-143. [CrossRef]

170. Singh, A.K.; DePauw, R.M.; Knox, R.E.; Clarke, J.M.; McCaig, T.N.; Cuthbert, R.D.; Ruan, Y. AAC Spitfire durum wheat. Can. J. Plant Sci. 2016, 97, 157-164. [CrossRef]

171. Pozniak, C.J.; Clarke, J.M. CDC precision durum wheat. Can. J. Plant Sci. 2017, 97, 344-348. [CrossRef]

172. Pozniak, C.J.; Clarke, J.M. CDC dynamic durum wheat. Can. J. Plant Sci. 2017, 97, 380-384. [CrossRef]

173. Pozniak, C.J.; Clarke, J.M. CDC alloy durum wheat. Can. J. Plant Sci. 2017, 97, 385-389. [CrossRef]

174. Ruan, Y.; Singh, A.K.; DePauw, R.M.; Knox, R.E.; McCaig, T.N.; Cuthbert, R.D.; McCallum, B.; Fetch, T.; Beres, B. AAC Congress durum wheat. Can. J. Plant Sci. 2017, 98, 483-491. [CrossRef]

175. Clarke, F.R.; Clarke, J.M.; DePauw, R.M.; Fernandez, M.R.; Fox, S.; Gilbert, J.; Humphreys, G.; Knox, R.E.; McCaig, T.N.; Procunier, D.; et al. Strategic approach to mitigating weather induced defects of wheat quality. Euphytica 2005, 143, 285-290. [CrossRef]

176. Knox, R.E.; Clarke, F.R.; Clarke, J.M.; Fox, S.L.; DePauw, R.M.; Singh, A.K. Enhancing the identification of genetic loci and transgressive segregants for preharvest sprouting resistance in a durum wheat population. Euphytica 2012, 186, 193-206. [CrossRef]

177. DePauw, R.M.; Knox, R.E.; Singh, A.K.; Fox, S.L.; Humphreys, D.G.; Hucl, P. Developing standardized methods for breeding preharvest sprouting resistant wheat, challenges and successes in Canadian wheat. Euphytica 2012, 188, 7-14. [CrossRef]

178. Singh, A.K.; Knox, R.E.; Clarke, J.M.; Clarke, F.R.; Singh, A.; DePauw, R.M.; Cuthbert, R.D. Genetics of pre-harvest sprouting resistance in a cross of Canadian adapted durum wheat genotypes. Mol. Breed. 2014, 33, 919-929. [CrossRef] [PubMed]

179. Chao, S.; Elias, E.; Benscher, D.; Ishikawa, G.; Huang, Y.F.; Saito, M.; Nakamura, T.; Xu, S.; Faris, J.; Sorrells, M. Genetic mapping of major-effect seed dormancy quantitative trait loci on chromosome $2 \mathrm{~B}$ using recombinant substitution lines in tetraploid wheat. Crop Sci. 2016, 56, 59-72. [CrossRef]

180. Codex-Alimentarius-Commission. Report of the 36th Session of the Codex Committee on Food Additives and Contaminants; FAO/WHO: Rome, Italy, 2004.

181. Wiebe, K.; Harris, N.S.; Faris, J.D.; Clarke, J.M.; Knox, R.E.; Taylor, G.J.; Pozniak, C.J. Targeted mapping of Cdu1, a major locus regulating grain cadmium concentration in durum wheat (Triticum turgidum, L. var durum). Theor. Appl. Genet. 2010, 121, 1047-1058. [CrossRef] [PubMed]

182. Anonymous. Varieties of Grain Crops; Saskatchewan Ministry of Agriculture: Regina, SK, Canada, 2018 ; p. 32. 
183. Anderson, J.A. Marker-assisted selection for Fusarium head blight resistance in wheat. Int. J. Food Microbiol. 2007, 119, 51-53. [CrossRef] [PubMed]

184. Somers, D.J.; Fedak, G.; Clarke, J.; Cao, W. Mapping of FHB resistance QTLs in tetraploid wheat. Genome 2006, 49, 1586-1593. [CrossRef] [PubMed]

185. Ruan, Y.; Comeau, A.; Langevin, F.; Hucl, P.; Clarke, J.M.; Brule-Babel, A.; Pozniak, C.J. Identification of novel QTL for resistance to Fusarium head blight in a tetraploid wheat population. Genome 2012, 55, 853-864. [CrossRef] [PubMed]

186. Barker, P.S.; McKenzie, R.I.H. Possible sources of resistance to the wheat midge in wheat. Can. J. Plant Sci. 1996, 76, 689-695. [CrossRef]

187. Thomas, J.; Fineberg, N.; Penner, G.; McCartney, C.; Aung, T.; Wise, I.; McCallum, B. Chromosome location and markers of Sm1: A gene of wheat that conditions antibiotic resistance to orange wheat blossom midge. Mol. Breed. 2005, 15, 183-192. [CrossRef]

188. Smith, M.A.H.; Lamb, R.J.; Wise, I.L.; Olfert, O.O. An interspersed refuge for Sitodiplosis mosellana (Diptera: Cecidomyiidae) and a biocontrol agent Macroglenes penetrans (Hymenoptera: Pteromalidae) to manage crop resistance in wheat. Bull. Entomol. Res. 2004, 94, 179-188. [CrossRef] [PubMed]

189. Smith, M.A.H.; Wise, I.L.; Lamb, R.J. Survival of Sitodiplosis mosellana (Diptera: Cecidomyiidae) on wheat (Poaceae) with antibiosis resistance: Implication for the evolution of virulence. Can. Entomol. 2007, 139, 133-140. [CrossRef]

190. Clarke, F.R.; Clarke, J.M.; Knox, R.E. Inheritance of stem solidness in eight durum wheat crosses. Can. J. Plant Sci. 2002, 82, 661-664. [CrossRef]

191. Nilsen, K.T.; N’Diaye, A.; MacLachlan, P.R.; Clarke, J.M.; Ruan, Y.; Cuthbert, R.D.; Knox, R.E.; Wiebe, K.; Cory, A.T.; Walkowiak, S.; et al. High density mapping and haplotype analysis of the major stem-solidness locus SSt1 in durum and common wheat. PLoS ONE 2017, 12, e0175285. [CrossRef] [PubMed] 